\title{
Mathematical Modelling for Drying Kinetics of Asparagus Roots (Asparagus Racemosus L.) and Determination of Energy Consumption
}

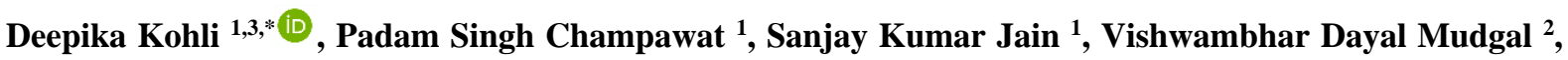 \\ Navin Chand Shahi ${ }^{3}$ \\ 1 Department of Processing and Food Engineering, CTAE, Maharana Pratap University of Agriculture and Technology, \\ Udaipur-313001 \\ 2 College of Dairy and Food Technology, Maharana Pratap University of Agriculture and Technology, Udaipur-313001 \\ 3 Department of Post-Harvest Process and Food Engineering, G. B. Pant University of Agriculture and Technology, \\ Pantnagar-263145 \\ * Correspondence: deepikaprp27@gmail.com;
}

Scopus Author ID 57198782453

Received: 1.06.2021; Revised: 10.07.2021; Accepted: 14.07.2021; Published: 10.08.2021

\begin{abstract}
Asparagus roots were dried in four selected driers vacuum, fluidized bed, tray, and solar dryer at temperatures starting from 40 to $70{ }^{\circ} \mathrm{C}$. The drying kinetics of asparagus roots was studied with the analysis of the influence of all stated drying conditions on the drying rate, dehydration ratio, rehydration characteristic, color characteristics, and energy consumption. With an increase in the temperature required for drying asparagus, there is an increasing trend of dehydration ratio (DR) and decreasing trend of drying time. The rehydration characteristics are found to be increases with a decrease in drying temperature from $70-60^{\circ} \mathrm{C}$ but decrease with a further decrease in drying temperature from $60-40{ }^{\circ} \mathrm{C}$. The energy consumption based on the drying conditions showed great thermal sensitivity and was found higher for low-temperature drying. The results of color characteristics (Chroma, hue angle, and $\Delta \mathrm{E}$ ) showed that the cream color of roots was relatively unaffected by drying. However, the brightness of roots was observed to be increased. Eleven thin-layered drying mathematical models were applied to experimental data of different drying conditions, and the model best describing its behavior was selected based on the coefficient of determination $\left(\mathrm{R}^{2}\right)$, sum square error (SSE), and root mean square error (RMSE). All selected models give good fitting results $\left(\mathrm{R}^{2}>0.96\right)$ and found the cubic model as the most suitable model for all treatments $\left(\mathrm{R}^{2}>0.99\right)$.
\end{abstract}

Keywords: Drying kinetics; mathematical modeling; asparagus; color; rehydration characteristics; energy consumption.

(C) 2021 by the authors. This article is an open-access article distributed under the terms and conditions of the Creative Commons Attribution (CC BY) license (https://creativecommons.org/licenses/by/4.0/).

\section{Introduction}

Asparagus (Asparagus Racemosus L.) known as Shatavari in India, is a most vital medicinal plant used as traditional medicine in some parts of India. It includes 300 species worldwide, and 22 species have been noted in India [1]. It is an important herbal drug rich in steroids such as shatavarin I-VIII [2]. In Ayurveda, the roots of asparagus are known for their properties like fertility promotion, phyto-estrogenic, and hormone modulation in both females and males [3]. It has anti-depressant [4], neuroprotective [5], immunomodulatory [6], antianxiety, cardio-protective, anti-diarrheal [1], anti-bacterial [7], antiparasitic [8], antiepileptic [9], adaptogenic [10], antilithiatic [11], antihepatotoxic [12] activities and also used for 
treatment and cure of stomach ulcers [13]. It has been utilized as a galactagogue, anodyne, antispasmodic, diuretic, aphrodisiac, and nervine tonic. It is considered as the women's tonic and used as a natural regulator [7]. Despite its nutritional and medicinal composition, it is a high moisture medicinal plant, so it is highly perishable. Thus, it is prone to quick spoilage with poor shelf-stable properties and demands preservation to curtail its postharvest losses [14].

Drying, dehydration, or desiccation is the oldest and most generally used physical preservation method, wherein the growth and activity of enzymes and micro-organisms are hindered by lowering moisture content to a safe level and reducing the water activity of food material $[15,16]$. The methods and desiccation conditions play an essential role in the quality characteristics of final products. It substantially reduces the bulk, resulting in abridgment of handling costs and allowing storage in ambient conditions $[17,18]$. It also curtails chemical \& physical changes during storage. Since it is a highly energy-intensive process, new drying practices and driers are needed with minimum energy cost [19]. Several thin-layered drying mathematical models are already being utilized to determine the drying time [14]. Drying kinetics is significantly influenced by the velocity \& temperature of drying air and the thickness of the material. Physical and thermal properties, like moisture diffusivity and heat \& mass transfer data of food products, are essential for the perfect dryer design [20]. Drying kinetics and modeling of several fruits and vegetables have already been studied by countless researchers, jujube [21], banana [22], stevia [23], green apple peel [24], mango [25], lemon [26], mint leaves [27], sweet potato [28], tomato [29], cherry [30], etc. But, the drying kinetics of shatavari or asparagus roots has not been studied yet, and very limited data is available in the literature.

In drying, mathematical modeling plays a vital role in designing the dryer, regulating the process parameters, and optimizing the process [31]. Process models authenticated by drying experiments improve the energy efficiency \& predict the effect of parameters on drying time [32,33]. Drying characteristics can be defined by theoretical, semi-theoretical, and empirical modeling techniques [34]. Theoretical modeling is realistic and very well explains the process, but it also requires sufficient computational resources. Semi-theoretical models are commonly based on simplified Fick's second law of diffusion or modified version of any extensively used simple models. Empirical models use the direct relation of moisture content and drying time only [35]. Despite much available data on modeling techniques for the drying process in the literature, kinetics and mathematical modeling studies are still objective for development.

The aims of the present study are to (i) study the drying kinetics of asparagus roots, (ii) find out the finest model describing the drying characteristics of asparagus by relating experimental and predicted data, and (iii) determine the best drying conditions based on quality parameters.

\section{Materials and Methods}

\subsection{Raw material and preparation.}

The experiments were carried out using asparagus roots (Asparagus Racemosus L.), common medicinal plants harvested in equivalent standard format, and degree of maturity from Medicinal Plant Research and Development Centre (MRDC), Pantnagar, India. Proper care was taken so that the procured sample was uniform in size, shape and had no defects on a visual basis. It was stored at $4{ }^{\circ} \mathrm{C}$ to keep the roots fresh as much as possible to perform drying 
experiments. Before drying, samples were prepared by washing under running tap water, peeled, and after that sliced into 2-4 mm thick root. The samples were then blanched in water ( $80{ }^{\circ} \mathrm{C}$ for 5 minutes) [36] and instantly drained, weighed, and dried. The initial moisture content present in prepared roots was determined by the vacuum drying method [37].

\subsection{Drying equipment and procedure.}

The pretreated asparagus roots slices were dried by different drying methods, i.e., solar dryer, tray dryer (Cabinet type, INDOSAW), fluidized bed dryer (Macneill and Barry Limited), and vacuum dryer (Macro Scientific Works) with the optimal drying technology. Before initiating the experiments, the dryer was switched on without the prepared root sample for 56 min or until the constant required experimental temperature was attained. After attaining the stable condition, a pretreated asparagus roots slice was placed in the dish, and drying starts. On the basis of the literature reviewed, the drying temperature from 40 to $70{ }^{\circ} \mathrm{C}$ was selected with an interval of $10^{\circ} \mathrm{C}$. To determine dehydration curves, the moisture loss was noted by a digital balance (Mettler) in every one-hour intervals during drying till no or minimum change was observed in two consecutive weights of dried slices which is the final moisture content (4-6\%, w.b.). These experiments had been performed thrice, and the average was calculated and used for each treatment [38-40].

\subsection{Drying kinetics.}

The mechanism of moisture loss is a complex process. As drying proceeds, there is a decrease in moisture level, and then the mechanism changes to liquid diffusion defined by Ficks' second law, which is a widely used equation for explaining the dehydration process of most biotic materials during the falling rate period [41]. With the dry weight as initial moisture is already known, the amount of moisture ( $\mathrm{M}, \mathrm{g}$ moisture/g dry solid) at a given time was determined by an equation [42]:

$$
\mathrm{M}=\frac{\mathrm{W}-\mathrm{w}_{\mathrm{d}}}{\mathrm{w}_{\mathrm{d}}}
$$

where $\mathrm{W}$ is roots weight during drying at a time $\mathrm{t}$ and $\mathrm{W}_{\mathrm{d}}$ is a dry weight of roots $(\mathrm{g})$.

The average drying rate $\left(\left(\frac{\mathrm{dM}}{\mathrm{dt}}\right)_{\mathrm{avg}}, \%(\mathrm{~d} . \mathrm{b}.) / \mathrm{min}\right)$ at different times were calculated for all experimental drying conditions using the following equation [14].

$$
\left(\frac{\mathrm{dM}}{\mathrm{dt}}\right)_{\mathrm{avg}}=\frac{\mathrm{M}_{\mathrm{t}}-\mathrm{M}_{\mathrm{t}+\Delta \mathrm{t}}}{\Delta \mathrm{t}}
$$

where $\mathrm{M}_{\mathrm{t}}$ is the moisture content at any time $\mathrm{t}\left(\%\right.$ d.b.) and $\mathrm{M}_{\mathrm{t}+\Delta \mathrm{t}}$ is the moisture content after a time interval of $\Delta t(\%$ d.b.).

The overall rate of drying was also computed as equation [14]:

$$
\frac{\mathrm{dM}}{\mathrm{dt}}=\frac{\mathrm{M}_{\mathrm{O}}-\mathrm{M}_{\mathrm{F}}}{\mathrm{t}_{\mathrm{F}}}
$$

where $M_{F}$ is the moisture in the dried sample $(\mathrm{g}), \mathrm{M}_{\mathrm{o}}$ is moisture in the fresh sample $(\mathrm{g})$, and $\mathrm{t}_{\mathrm{F}}$ is the total time for drying ( $\mathrm{min}$ )

The moisture ratio (MR) curves explain drying behavior very well rather than the moisture content curve since the initial value is the same, i.e., one for all drying experiments. The findings were then utilized to forecast the best describing drying models for pretreated 
samples of sliced asparagus roots. The dimensionless moisture ratio (MR) was computed by using formula as follows [43]:

$$
\mathrm{MR}=\frac{M-M_{e}}{M_{o}-M_{e}}
$$

where, $\mathrm{M}_{\mathrm{o}}, \mathrm{M}_{\mathrm{e}}$, and $\mathrm{M}$ are the initial moisture content, i.e., at zero-time, equilibrium moisture content (EMC), and moisture content at time t ( $\min )$ (\% d.b.), respectively. Simplified MR as $\mathrm{M} / \mathrm{M}_{\mathrm{o}}$ instead of equation (4) could be used since $\mathrm{M}_{\mathrm{e}}$ is very small compared to $\mathrm{M}$ and $\mathrm{M}_{\mathrm{o}}$ $[44,45]$.

\subsection{Mathematical modeling of drying kinetics.}

Various research workers have proposed different grain drying models, which were further used by other researchers in drying of high moisture foods, and hence these proposed models should also describe the drying of asparagus roots. Drying curves data, i.e., calculated moisture ratios at different drying times obtained from all drying experiments, were fitted in widely used eleven thin-layer drying models describing the drying kinetics are mentioned in Table 1. The regression analysis was done using the curve fitting Toolbox in MATLAB R2019a (MathWork, USA) software to determine the constants of models. To evaluate the goodness of fit of selected models and select the best-fitted model, the correlation coefficient (R2) was considered the primary criterion [46]. The other parameters to select the best behavior describing model were selected as sum square errors (SSE), and root mean squares errors (RMSE) [47]. The best model was chosen with the highest correlation coefficient $\left(\mathrm{R}^{2}\right)$, the least RMSE, and SSE [48]. These statistical significant values can also be calculated as $[32,49]$ :

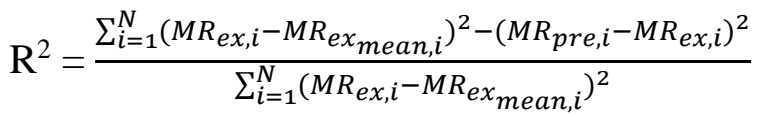

$$
\begin{aligned}
& \mathrm{RMSE}=\left[\frac{1}{N} \sum_{i=1}^{N}\left(M R_{\text {exp }, i}-M R_{p r e, i}\right)^{2}\right]^{1 / 2} \\
& \mathrm{SSE}=\frac{1}{N} \sum_{i=1}^{N}\left(M R_{\text {exp }, i}-M R_{\text {pre }, i}\right)^{2}
\end{aligned}
$$

where, $\mathrm{MR}_{\text {exp,i, }}$ and $\mathrm{MR}_{\text {pre,i, }}$ are the experimental and predicted dimensionless values of moisture ratio, respectively, and $\mathrm{N}$ is the total number of observations.

Table 1. Mathematical thin-layered drying models fitted to the drying curves of asparagus roots.

\begin{tabular}{c|c|c|c} 
S. No. & Model Name & Equations & References \\
\hline $\mathbf{1 .}$ & Lewis & $\mathrm{MR}=\mathrm{e}^{-\mathrm{kt}}$ & {$[50]$} \\
\hline $\mathbf{2 .}$ & Page & $\mathrm{MR}=\mathrm{e}^{-\mathrm{kt}^{\mathrm{n}}}$ & {$[51]$} \\
\hline $\mathbf{3 .}$ & Generalized Exponential & $\mathrm{MR}=\mathrm{a} \mathrm{e}^{-\mathrm{kt}}$ & {$[53]$} \\
\hline $\mathbf{4 .}$ & Logarithmic & $\mathrm{MR}=\mathrm{a} \mathrm{e} \mathrm{e}^{-\mathrm{kt}}+\mathrm{c}$ & {$[54]$} \\
\hline $\mathbf{5 .}$ & Henderson and Pabis model & $\mathrm{MR}=\mathrm{a} \mathrm{e}^{-\mathrm{kt}^{\mathrm{n}}}$ & {$[56]$} \\
\hline $\mathbf{6 .}$ & Midilli & $\mathrm{MR}=1-\frac{t}{(a+b t)}$ & {$[57]$} \\
\hline $\mathbf{7 .}$ & Peleg & $\mathrm{MR}=1+\mathrm{at}+\mathrm{bt}^{2}$ & {$[58]$} \\
\hline $\mathbf{8 .}$ & Wang and Singh & $\mathrm{MR}=\frac{a_{0}}{(1+a \exp (k t))}$ & {$[59]$} \\
\hline $\mathbf{9 .}$ & Logistic & $\mathrm{MR}=\mathrm{a}+\mathrm{bt}+\mathrm{ct}^{2}$ & {$[60]$}
\end{tabular}




\subsection{Rehydration characteristics and dehydration ratio.}

The rehydration characteristics (RC) of dried goods are general parameters for the quality index. The high rehydration characteristics signify a better quality dried food product because they designate that the physical and chemical changes may occur during dehydration [32]. Dried roots slices of $2 \mathrm{~g}$ were boiled in distilled water and salt solution of $150 \mathrm{ml}$ for 15 min for rehydration and then cooled. The samples were then taken out $\&$ adhered water was carefully absorbed in tissue papers, and weight was noted [61]. Triplicate of measurements was performed, and value was used for further calculation of rehydration ratio (RR), coefficient of rehydration (COR), and percent of water in rehydrated (POW) sample. These rehydration characteristics were calculated as follows $[62,63]$ :

$$
\begin{gathered}
\text { Rehydration Ratio }(\mathrm{RR})=\frac{W_{2}}{W_{1}} \\
\text { Coefficient of rehydration }=\frac{\mathrm{W}_{2} \times\left[100-\mathrm{M}_{1}\right]}{\left[\mathrm{W}_{1}-\mathrm{M}_{\mathrm{F}}\right] \times 100} \\
\text { Percent of water in rehydrated sample }=\left[\frac{\mathrm{W}_{2}-\mathrm{W}_{3}}{\mathrm{~W}_{3}}\right] \times 100
\end{gathered}
$$

where $\mathrm{M}_{\mathrm{F}}$ is the moisture present in dried roots used for calculating rehydration characteristics $(\mathrm{g}), \mathrm{M}_{1}$ is the initial moisture content of roots $(\%)$, and $\mathrm{W}_{1}, \mathrm{~W}_{2}$, and $\mathrm{W}_{3}$ is the weight of the dry roots used for rehydration $(\mathrm{g})$, drained weight of the rehydrated roots $(\mathrm{g})$ and dry matter content in the roots taken for rehydration $(\mathrm{g})$, respectively.

Dehydration ratio (DR) was calculated as the ratio of the fresh or initial weight of asparagus roots slices before drying and dried sample weight after removing from the drier $[64,65]$.

\subsection{Color.}

The color parameters $\left(\mathrm{L}^{*}, \mathrm{a}^{*}\right.$, and $\left.\mathrm{b}^{*}\right)$ of fresh as well as dehydrated asparagus roots were obtained by a Hunter lab Color Analyzer (Labscan XE). $\mathrm{L}^{*}$ ranges from black to white as 0 to 100 , which specifies lightness/darkness, $a *$ and $b *$ specifies the redness/greenness \& yellowness/blueness, respectively [66,67]. A negative value of $a^{*}$ and $b^{*}$ designates green and blue color, respectively, while positive values of both specify red-purple and yellow color, respectively. The $\mathrm{L}_{0}^{*}, \mathrm{a}_{0}^{*}$, and $\mathrm{b}_{0}{ }^{*}$ for fresh and $\mathrm{L}^{*}, \mathrm{a}^{*}$ and $\mathrm{b}^{*}$ color values for dried were noted after standardizing the analyzer each time with a white ceramic plate. Triplicate readings were taken for all dried root samples. In order to estimate the color changes, the three different color parameters viz. Hue angle $\left(\mathrm{h}^{\circ}\right)$, Chroma $(\mathrm{C})$, and total color difference $(\Delta \mathrm{E})$ values were measured [68]. The hue angle (in degrees): $0^{\circ}$ (red), $90^{\circ}$ (yellow), $180^{\circ}$ (green), $270^{\circ}$ (blue) was calculated using $\mathrm{a}^{*}$ and $\mathrm{b}^{*}$ values, and chroma indicates the color saturation while a higher $\Delta \mathrm{E}$ represents a larger color difference in comparison to reference fresh roots. The given parameters were calculated according to the following equations [14]:

$$
\begin{gathered}
\mathrm{h}^{\circ}=\tan ^{-1}\left(\frac{b}{a}\right) \\
\Delta \mathrm{E}=\sqrt{\left(L^{*}-L^{*}{ }_{0}\right)^{2}+\left(a^{*}-a^{*}{ }_{0}\right)^{2}+\left(b^{*}-b^{*}{ }_{0}\right)^{2}}
\end{gathered}
$$




$$
\text { Chroma }=\sqrt{a^{* 2}+b^{* 2}}
$$

\subsection{Energy consumption.}

Energy requirement in drying expressed as $\mathrm{kWh}$ is the energy input to obtain the final dried products or energy used to dehydrate the asparagus to equilibrium or safe moisture content [69]. The energy supplied to the dryers for all experimental temperatures was measured by using a single-phase kilowatt-hour meter whose one unit gives the direct consumption of electricity in $\mathrm{kWh}[14]$.

\subsection{Statistical analysis.}

The two factors were the different drying methods (Vacuum, Tray, Fluidized bed, and Solar) and the drying temperatures $\left(40,50,60\right.$, and $\left.70{ }^{\circ} \mathrm{C}\right)$. These experiments were performed thrice, and the data obtained was then subjected to one-way analysis of variance (ANOVA), and means were also separated using post hoc Duncan's multiple range test in statistical package SPSS version 26 statistical software (IBM Corporation, New York). Mean were considered significantly different for $\mathrm{p}<0.05$ level.

\section{Result and Discussion}

\subsection{Drying kinetics of asparagus roots.}

The relation of moisture change with respect to the required drying period obtained by different drying methods of asparagus roots is given in Figure 1, which clearly shows a nonlinear continuous decrease in moisture with the drying period. The variation of drying air temperature has been found reflected in values of the drying period. The total drying period and the drying temperature are inversely proportional to each other; as the drying temperature decreases, the drying period is prolonged. The drying of highly perishable asparagus roots was continued from the initial moisture $637.71 \%$ (d.b.) to the ultimate harmless moisture level of 4-6\% (d.b) [14]. The drying time ranged from $240 \mathrm{~min}$ (in the fluidized-bed dryer, at $70^{\circ} \mathrm{C}$ ) to $540 \mathrm{~min}$ (in a tray dryer, solar dryer, and vacuum dryer at $40^{\circ} \mathrm{C}$ ), being generally lower at high drying temperatures. With the increment in drying temperature, the total time of drying roots was significantly reduced $(\mathrm{p}<0.01)$ due to the increased heat supply rate, which accelerates the water migration [70]. Drying time for fluidized-bed drying at $70,60,50,40{ }^{\circ} \mathrm{C}$ was 180,240 , $300,360 \mathrm{~min}$, respectively. By working at $70{ }^{\circ} \mathrm{C}$ instead of 60,50 , and $40{ }^{\circ} \mathrm{C}$, drying time up to safe moisture could be shortened by nearly $1.2,1.6$, and 2 times, respectively. Similar relations were reported by several authors [71-73]. The drying time for different driers was also significantly varied $(\mathrm{p}<0.01)$. According to Figure 1 , it can be understood that the fluidizedbed and tray drying was the fastest and slowest method of drying, respectively, for the same temperature of drying. 
Figure 1a

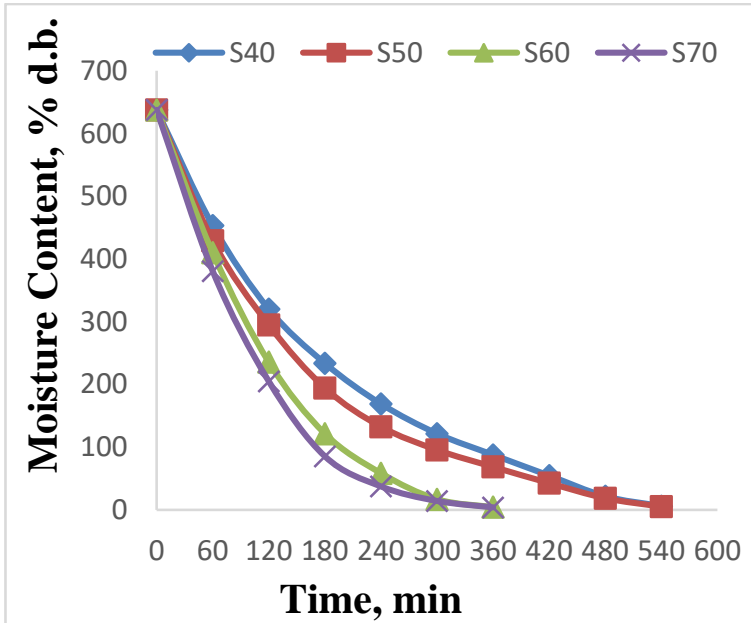

Figure 1c

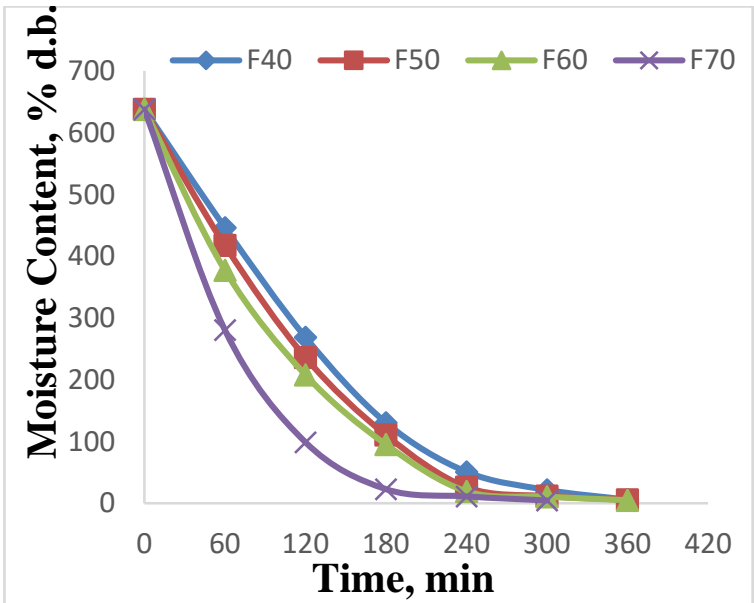

Figure $1 b$

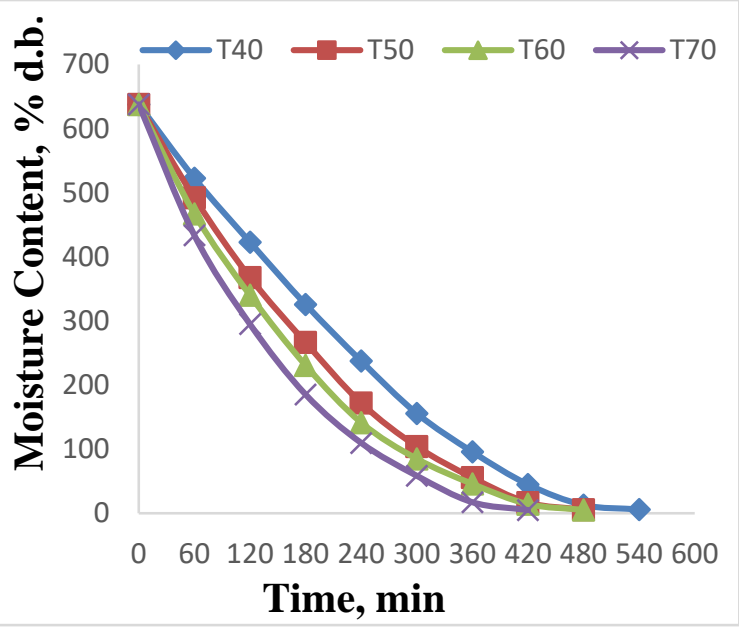

Figure 1d

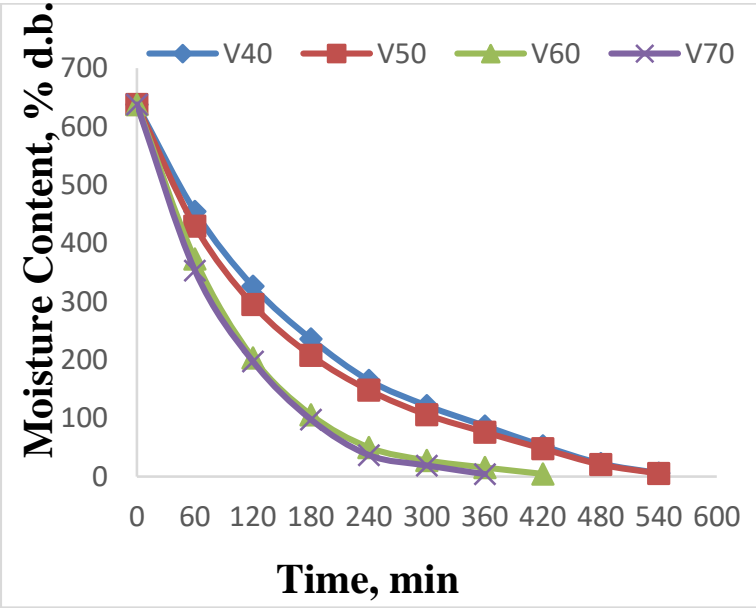

Figure 1. Moisture content versus drying time for asparagus root slices at different drying temperatures (a) for solar dryer; (b) for tray dryer; (c) for fluidized bed dryer; (d) for vacuum dryer.

In Figure 2, the average drying rates of dried asparagus roots can be seen, according to which initially, moisture decreases rapidly and non-linearly, and then the decrease in moisture slows down considerably in the final stage. The drying rate decreases with a decrease in moisture content, and few points of curves interacted unexpectedly. This was maybe due to variations in experiments [14]. For the first 120 minutes, the decrease in moisture was $317.623 \%$, and for the next 120 minutes, the decrease was $151.066 \%$, and so on. During these initial stages of the dehydration, moisture of roots was very high, and hence high moisture diffusion occurred due to this drying rate was also higher. For the last minutes, the decrease was only $15.762 \%$. In this final stage, the drops in drying rates are due to the reduction in moisture. For example, in the solar dryer at $40{ }^{\circ} \mathrm{C}$, for initial $60 \mathrm{~min}$ rate was $3.08 \%$ (d.b.)/min, and for the last minutes, the rate decreases to $0.263 \%$ (d.b.)/min. The drying kinetics of asparagus roots showed that the average rate decreases significantly with decreased drying temperatures. Several researchers reported similar results for drying various fruits, vegetables, and crops $[44,73,74]$. From curves, it is visible that a constant-rate drying period was not detected for the entire duration of drying. The reduction in the moisture process occurred in falling-rate only, representing that the critical moisture content is identical to the initial moisture. This also indicates that moisture diffusion during drying is responsible for moisture movement in the asparagus root slices. This finding was comparable with other literature reviewed on drying kinetics of numerous foods $[38,59,71]$. The result of the overall drying rate 
was also similar to the average drying rate. The overall drying rate significantly varies $(\mathrm{p}<0.05)$ from 1.17 to $2.11 \%$ (d.b.)/min for all variables in the study. Normally, it can be expected that the overall drying rate should also be higher at higher temperatures, which is clearly reflected by the results. Overall drying rate linearly decreases with a decrease in temperature from 70 to $40{ }^{\circ} \mathrm{C}$ with the agreement of previous literature on drying characteristics of biological materials $[14,52]$.

Figure 2a

Figure $2 b$
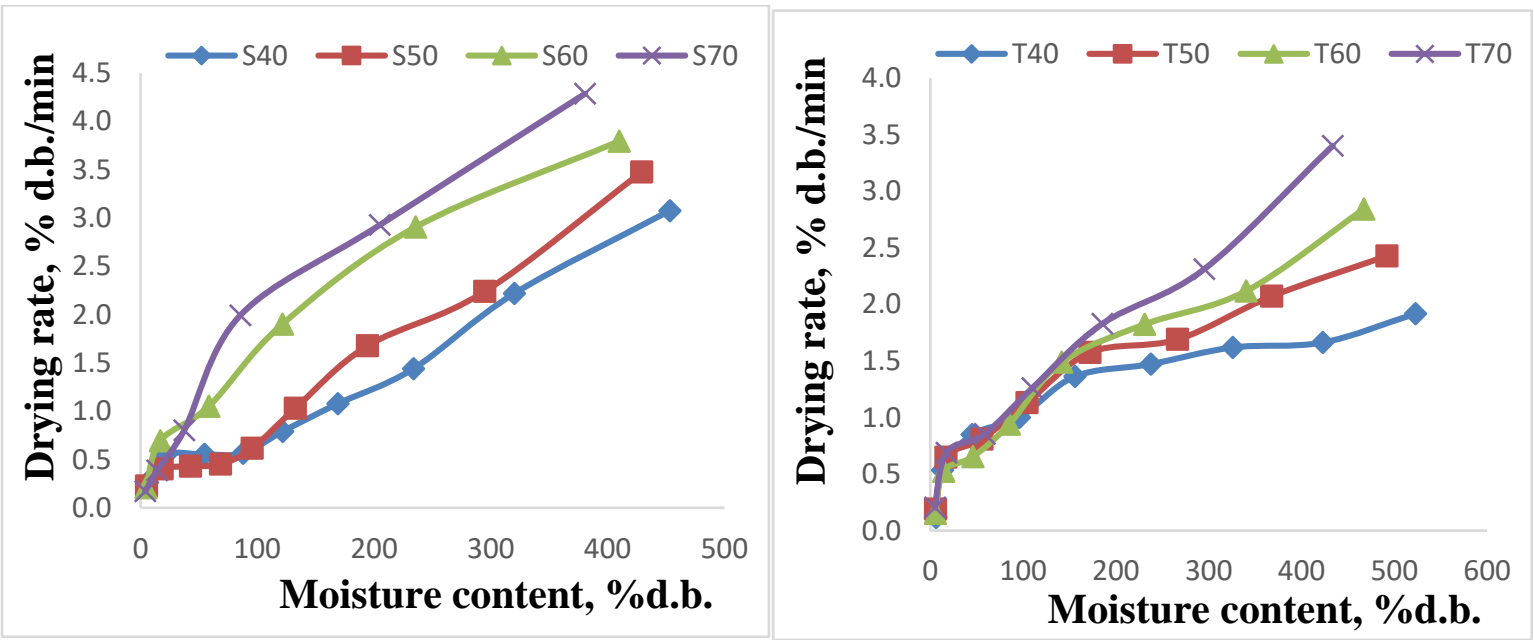

Figure 2c

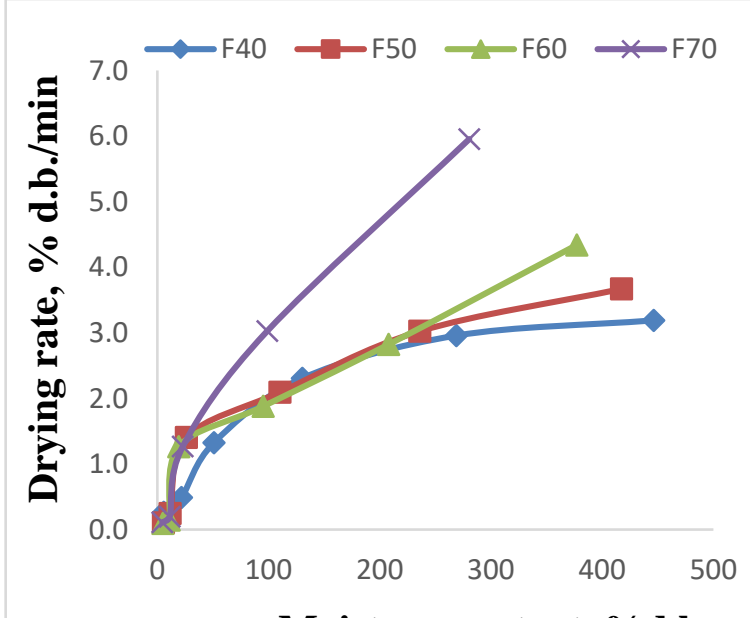

Moisture content, \%d.b.

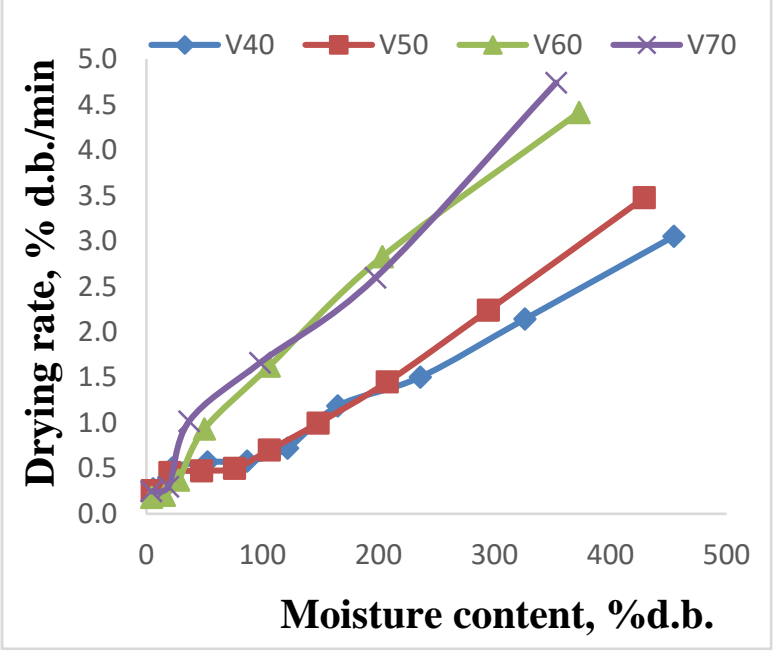

Figure 2. Drying rate versus moisture content for asparagus root slices at different drying temperature (a) for solar dryer; (b) for tray dryer; (c) for fluidized bed dryer; (d) for vacuum dryer.

\subsection{Mathematical modeling.}

The change of dimensionless moisture ratios related to the drying period used for the fitting of drying models is shown in Figure 3. As there was no appearance of the constant-rate period in experimental drying curves, those models that better define the drying in falling rate period were only used. All the models gave satisfactory results with high coefficient of determination $\left(\mathrm{R}^{2}\right)$ values ranging between 0.9642-1.0000, low values SSE, and RMSE values ranging between 0.00000539 to 0.03428 , respectively. For all drying, the value of $\mathrm{R}^{2}$ for all selected models was found greater than 0.96 , indicating that all models gave outstanding fitting results for all the experimental drying data. Among all the thin-layer drying models, the Cubic model was considered the best model since it describes the change in moisture values over time 
with the highest average $\mathrm{R}^{2}$ value, low average SSE \& average RMSE value for almost all sets of experimental data. The detailed statistical analysis of the cubic model, including coefficient of determination $\left(\mathrm{R}^{2}\right)$, sum square errors (SSE), and root mean squares errors (RMSE), and model's constants are summarized in Table 2 and Table 3, respectively. For few data, the cubic model gave the highest $\mathrm{R}^{2}$ of 1.00 at drying conditions of fluidized bed drying and vacuum drying, at $70^{\circ} \mathrm{C}$, and $60^{\circ} \mathrm{C}$, respectively. All other models also give good results of fitting in the descending sequence of best goodness of fit as Logistic, Logarithmic, Henderson and Pabis, Midilli, Page, Peleg, Parabolic, Wang and Sang, Generalized exponential, and lastly, the Lewis models.

All models are further validated by comparing residuals of experimental and predicted values of moisture ratio. Figure 4 shows residual plots of models for thin-layer drying roots in fluidized bed drying at $70{ }^{\circ} \mathrm{C}$. It can be observed that the results obtained from the Cubic and Logistic models are just near to the experimental dehydration data. The minimum residual data indicates that the models, i.e., Cubic and Logistic models, could be satisfactorily used to predict the drying behavior of asparagus roots. Few models like Logistic, Peleg, Parabola, Wang, and Sang, and Cubic were not investigated for asparagus roots and hence never selected as the best model in the literature. Previous studies used empirical models (Modified Page, Lewis, and Logarithmic) for convective air drying of onion and concluded that the selected list of models very well described the drying kinetics [75].

Figure $3 \mathrm{a}$

Figure $3 b$

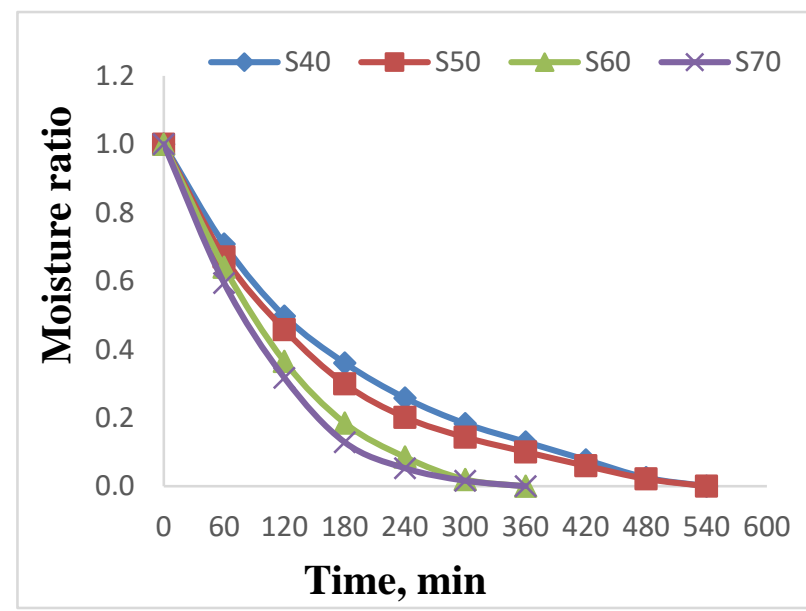

Figure $3 \mathrm{c}$

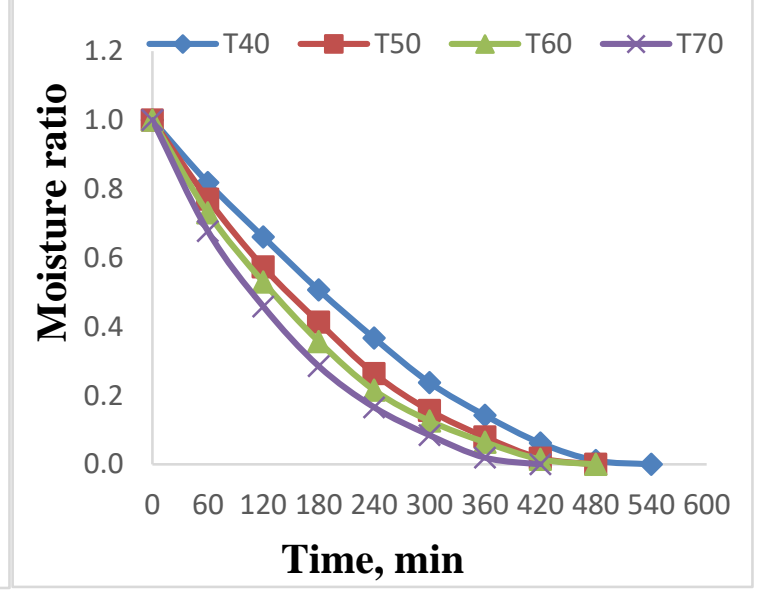

Figure $3 d$

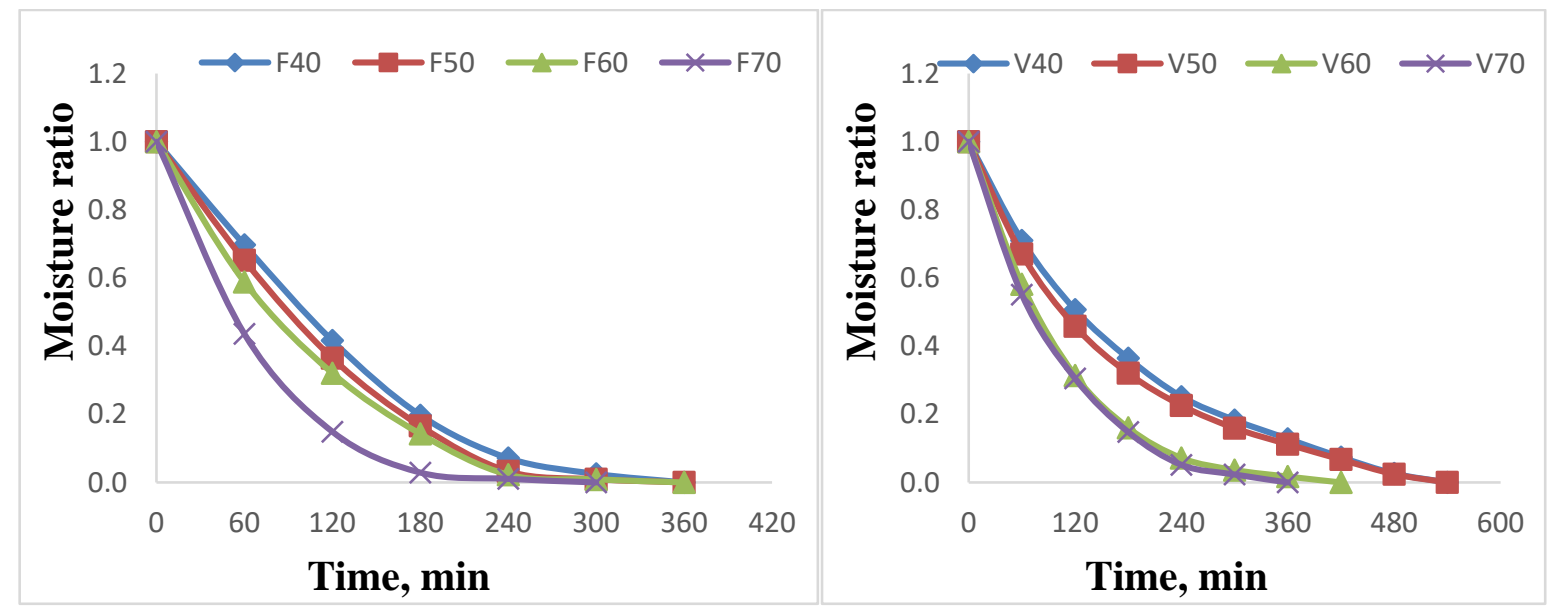

Figure 3. Moisture ratio versus drying time for asparagus root slices at different drying temperatures (a) for solar dryer; (b) for tray dryer; (c) for fluidized bed dryer; (d) for vacuum dryer. 


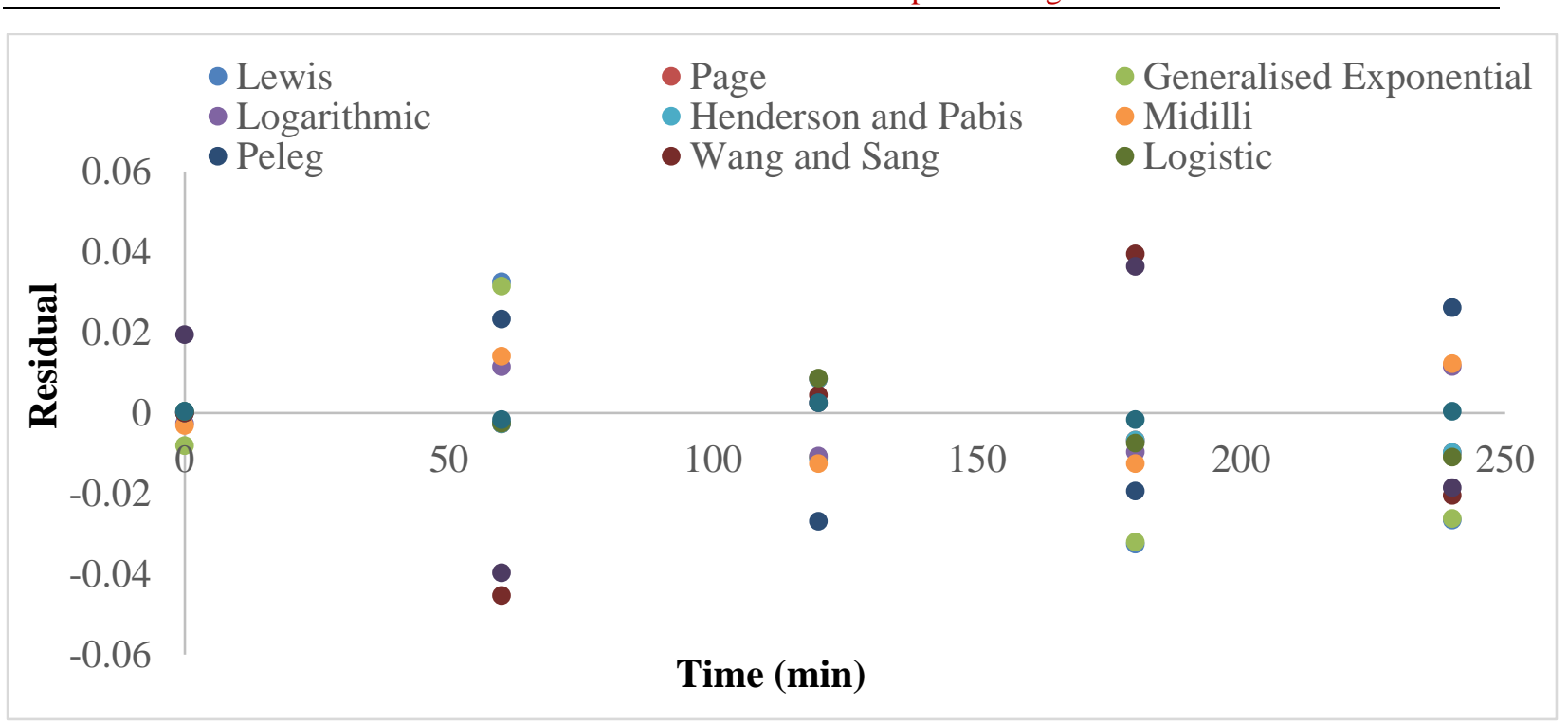

Figure 4. Residual plot of single-layer drying models of asparagus in a fluidized bed at $70{ }^{\circ} \mathrm{C}$.

Table 2. Statistical values for cubic model for different drying conditions

\begin{tabular}{|c|c|c|c|c|c|c|}
\hline S.No. & Drying Method & Constant & $40^{\circ} \mathrm{C}$ & $50^{0} \mathrm{C}$ & $60^{\circ} \mathrm{C}$ & $7^{\circ} \mathrm{C}$ \\
\hline \multirow[t]{3}{*}{1} & \multirow[t]{3}{*}{ Tray } & $\mathbf{R}^{2}$ & 0.9999 & 0.9999 & 0.9998 & 0.9998 \\
\hline & & SSE & 0.0000799 & 0.0000873 & 0.000174 & 0.0001156 \\
\hline & & RMSE & 0.004 & 0.00467 & 0.0066 & 0.00621 \\
\hline \multirow[t]{3}{*}{2} & \multirow[t]{3}{*}{ Solar } & $\mathbf{R}^{2}$ & 0.9998 & 0.9998 & 0.9997 & 0.9999 \\
\hline & & SSE & 0.0001507 & 0.0002122 & 0.0002479 & 0.0001028 \\
\hline & & RMSE & 0.00549 & 0.006514 & 0.01113 & 0.007169 \\
\hline \multirow[t]{3}{*}{3} & \multirow[t]{3}{*}{ Vacuum } & $\mathbf{R}^{2}$ & 0.9994 & 0.9996 & 1 & 0.9998 \\
\hline & & SSE & 0.0005163 & 0.0003795 & 0.00000539 & 0.0001062 \\
\hline & & RMSE & 0.01016 & 0.008712 & 0.001641 & 0.0103 \\
\hline \multirow[t]{3}{*}{4} & \multirow{3}{*}{$\begin{array}{l}\text { Fluidized bed } \\
\text { drying }\end{array}$} & $\mathbf{R}^{2}$ & 0.9999 & 0.9999 & 0.9996 & 1 \\
\hline & & SSE & 0.0001013 & 0.0000666 & 0.0002911 & 0.0000123 \\
\hline & & RMSE & 0.007117 & 0.005771 & 0.01206 & 0.003508 \\
\hline
\end{tabular}

Table 3. Estimated values of coefficients for cubic models for different drying conditions

\begin{tabular}{|c|c|c|c|c|c|c|}
\hline S.No. & Model & Constant & $40^{\circ} \mathrm{C}$ & ${ }^{50^{0} \mathrm{C}}$ & $60^{\circ} \mathrm{C}$ & $7^{\circ} \mathrm{C}$ \\
\hline \multirow[t]{4}{*}{1} & \multirow{4}{*}{$\begin{array}{c}\text { Cubic (tray } \\
\text { drying) }\end{array}$} & $\mathbf{A}$ & 0.9976 & 0.9994 & 0.9985 & 0.9978 \\
\hline & & B & -0.002936 & -0.004044 & -0.004772 & -0.005933 \\
\hline & & $\mathrm{C}$ & $7.367 \mathrm{e}-07$ & $4.376 \mathrm{e}-06$ & $7.386 \mathrm{e}-06$ & $1.301 \mathrm{e}-05$ \\
\hline & & D & $2.331 \mathrm{e}-09$ & $-6.605 e-10$ & $-3.717 e-09$ & $-1.085 \mathrm{e}-08$ \\
\hline \multirow[t]{4}{*}{2} & \multirow{4}{*}{$\begin{array}{c}\text { Cubic (solar } \\
\text { drying) }\end{array}$} & $\mathbf{A}$ & 0.9972 & 0.9956 & 1.002 & 1 \\
\hline & & B & -0.006044 & -0.006641 & -0.007546 & -0.008097 \\
\hline & & $\mathrm{C}$ & $1.362 \mathrm{e}-05$ & $1.588 \mathrm{e}-05$ & $1.694 \mathrm{e}-05$ & $1.985 \mathrm{e}-05$ \\
\hline & & D & $-1.112 \mathrm{e}-08$ & $-1.324 \mathrm{e}-08$ & $-9.051 e-09$ & $-1.311 \mathrm{e}-08$ \\
\hline \multirow[t]{4}{*}{3} & \multirow{4}{*}{$\begin{array}{c}\text { Cubic (Vacuum } \\
\text { drying) }\end{array}$} & $\mathbf{A}$ & 1.002 & 0.9937 & 0.9998 & 0.9988 \\
\hline & & B & -0.005928 & -0.006348 & -0.008666 & -0.009261 \\
\hline & & $\mathrm{C}$ & $1.431 \mathrm{e}-05$ & $1.6 \mathrm{e}-05$ & $2.679 \mathrm{e}-05$ & $3.532 \mathrm{e}-05$ \\
\hline & & D & $-1.305 \mathrm{e}-08$ & $-1.474 \mathrm{e}-08$ & $-2.992 \mathrm{e}-08$ & $-5.461 \mathrm{e}-08$ \\
\hline \multirow[t]{4}{*}{4} & \multirow{4}{*}{$\begin{array}{l}\text { Cubic (fluidized } \\
\text { bed drying) }\end{array}$} & $\mathbf{A}$ & 1.001 & 0.9998 & 0.997 & 0.9996 \\
\hline & & B & -0.00531 & -0.006349 & -0.007712 & -0.01209 \\
\hline & & $\mathrm{C}$ & $9.796 \mathrm{e}-07$ & $7.769 \mathrm{e}-06$ & $1.902 \mathrm{e}-05$ & $5.063 \mathrm{e}-05$ \\
\hline & & D & $1.914 \mathrm{e}-08$ & $7.634 \mathrm{e}-09$ & $-1.468 \mathrm{e}-08$ & $-7.339 \mathrm{e}-08$ \\
\hline
\end{tabular}

\subsection{Rehydration characteristics and dehydration ratio.}

The effect of the different drying methods and drying temperature on all rehydration characteristics (RR, COR, and POW) are presented shown in Table 4 and Figure 5. The presented results show that the RR, COW, and POW of asparagus roots for different drying conditions vary statistically significantly ( $\mathrm{p}<0.01$ ) from 4.23 to $5.28,0.6$ to 0.725 , and 77.49 to $81.52 \%$, respectively. The rehydration ratio was observed to be constantly increased as the drying temperatures increased from 40 to $60{ }^{\circ} \mathrm{C}$, whereas it was decreased for further drying 
air temperature increase from 60 to $70{ }^{\circ} \mathrm{C}$, probably due to case hardening asparagus roots slice's surface. Higher cellular breakdown at very high temperatures leads to decrease water absorption capacities (WAC) and hence poor rehydration characteristics. A similar trend like rehydration ratio was noticed with superior COR and POW at $60{ }^{\circ} \mathrm{C}$. Similar directly proportional relation of drying temperature on rehydration ratio was reported for convective air drying. The reason may be less shrinkage of dried roots at higher drying temperatures as the moisture removal rate is very fast. [38,74]. However, all parameters of rehydration characteristics were comparatively poor at low temperature dried product maybe because of longer drying period and hence the poor texture of asparagus roots. It was observed that the roots dried at $60{ }^{\circ} \mathrm{C}$ almost come to the initial shape after rehydration as the coefficient of rehydration \& percent water of rehydrated sample was recorded higher and nearby to fresh roots $[14,36]$. It can be concluded that while drying, the tissue of the asparagus roots was imposed irreversible structural damages, which results in the loss of rehydration ability. The results obtained can also correlate very well that the loosed and porous structure is formed after drying of roots. During heating in drying, cell wall disrupted as macromolecule separates from moisture which leads surface to be flat \& sturdy and hence lowers the rehydration characteristics [32].

According to Table 4, which reveals the variation of dehydration ratio (DR) with different drying conditions, the ratio significantly $(\mathrm{p}<0.01)$ varies from 4.441 to 7.482 . It can be seen that there is a significant difference, although samples dried at $70{ }^{\circ} \mathrm{C}$ showed a better ratio in comparison to those dehydrated by lower drying temperature conditions. The results reveal that the dehydration ratio markedly decreased with decreased drying temperature from 70 to $40{ }^{\circ} \mathrm{C}$, which indicated that the reduction in bulk weight of roots is maximum at a higher drying temperature. A similar result was also mentioned by other researchers $[14,65]$.

\subsection{Color.}

The color of fresh and dry food has a great impact on consumers' quality and acceptability of the product. The values $\Delta \mathrm{E}$, chroma, and hue observed for asparagus roots dried in different conditions are shown in Table 4 and Figure 6. The measured color characteristics of the fresh material were found to be $L^{*}$ as 44.55 , $a^{*}$ as 7.43 , and $b^{*}$ as 22.45 . Analyzing the color results, it can be observed that the variables $\Delta \mathrm{E}$, chroma, and hue presented significant differences $(\mathrm{p}<0.01)$ among the different drying conditions. The lightness was observed to be different for different drying conditions and was lower at higher drying temperatures. Color difference $(\Delta \mathrm{E})$ which represents overall color change after drying, relates to the good quality processed product with minimum $\Delta \mathrm{E}$ value [14]. The vacuum and solar treatments resulted in a lower change in $\mathrm{L}^{*}$ value and hence similar results in the $\Delta \mathrm{E}$ value as compared to the tray and fluidized bed air drying. This result was mainly related to vacuum dying situations where drying was underneath sub-atmospheric pressures, which countered the color detriment and produced a superior quality than other drying processes [68]. The hue angle $\left(\mathrm{h}^{\circ}\right)$ of the dry sample significantly vary for different drying experiments $(\mathrm{p}<0.01)$ but was not that much different from the fresh product (71.65). This indicates the change in the cream color of roots (combination of yellow $\left(\mathrm{b}^{*}\right)$ and red color $\left(\mathrm{a}^{*}\right)$ attributes) was not significant. Chroma values used to observe the color intensity were significantly different for all drying processes $(\mathrm{p}<0.01)$. When related to the non-dried asparagus roots, chroma values were not that much different (23.65). The chroma of the dried product shows a small change in the 
saturation. Thus, the cream color of roots was found practically unaffected, but brightness found increased after drying. A similar result was reported by several researchers $[14,36]$.

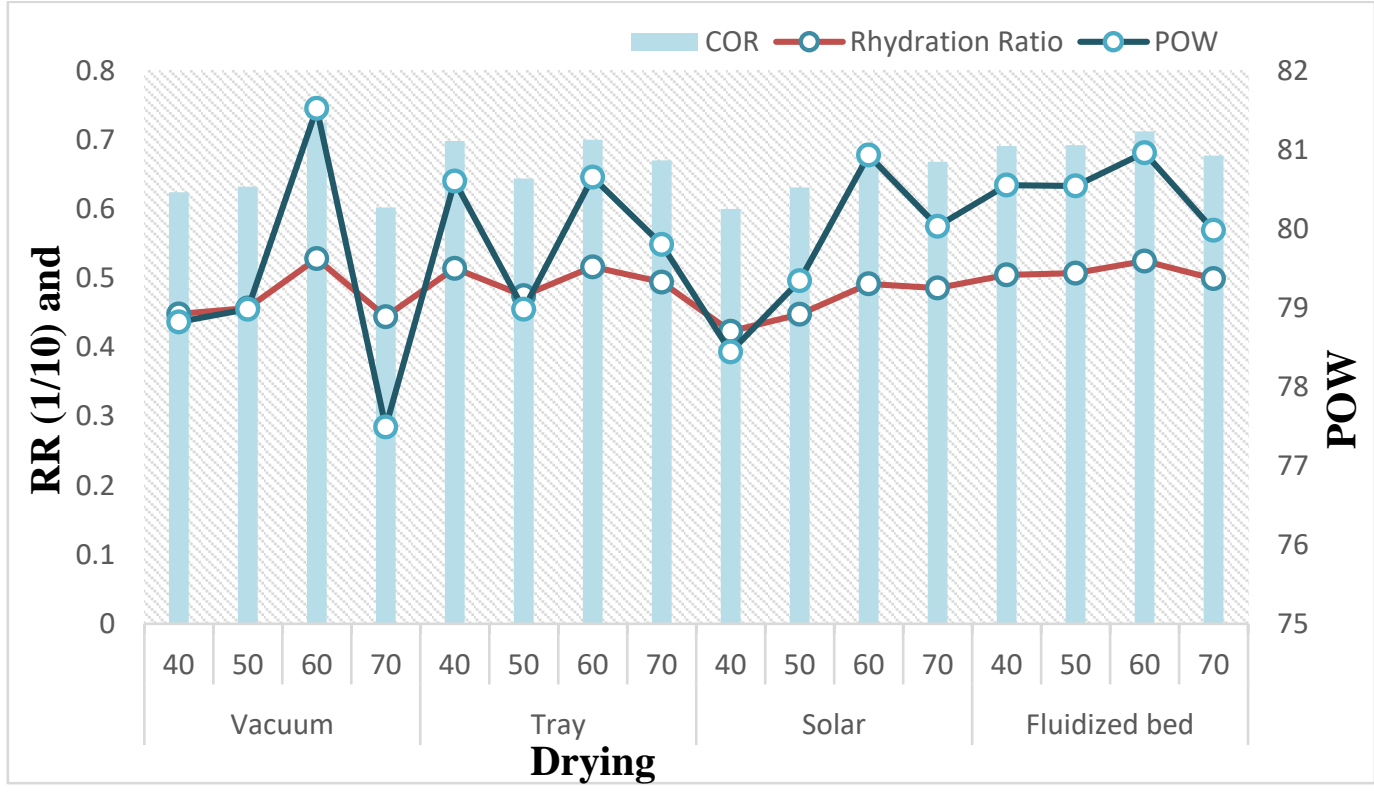

Figure 5. Rehydration characteristics of dried asparagus roots.

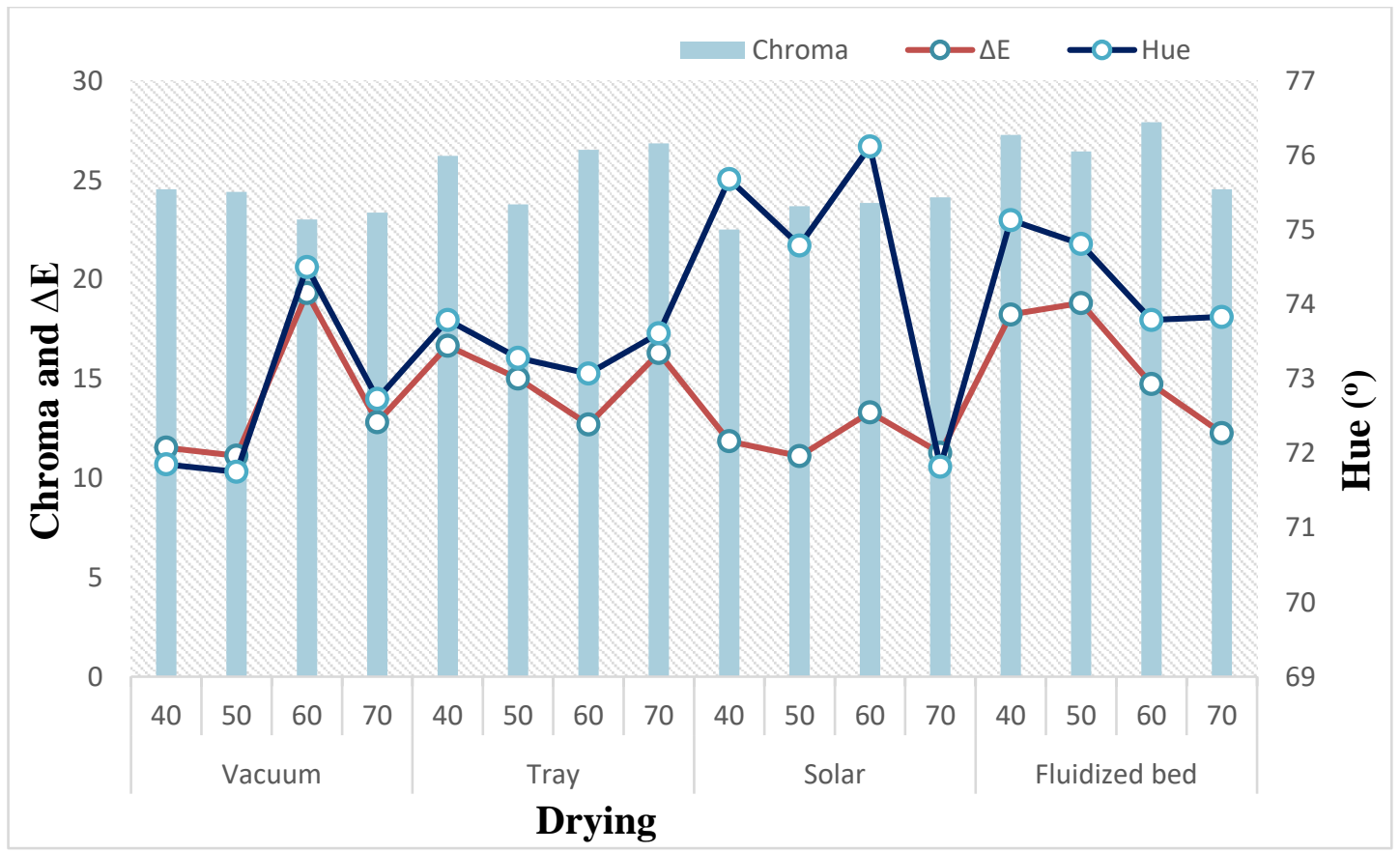

Figure 6. Color characteristics of dried asparagus roots

\subsection{Energy consumption.}

Figure 7 shows the obtained energy consumption (E) during the drying of asparagus roots under various drying conditions. The energy consumed by different dryers at different drying conditions significantly ( $\mathrm{p}<0.01$ ) varies from 3 to $28 \mathrm{kWh}$ to complete drying. Overall, when the four selected drying methods were related in terms of energy consumption, it was found that the vacuum drying method had the highest value, followed by tray, solar, and fluidized bed drying methods. The energy consumption $(E)$ of vacuum dryers at $70,60,50$, and $40{ }^{\circ} \mathrm{C}$ was $21,24,27$, and $28 \mathrm{kWh}$, respectively, which is significantly higher than those of other drying treatments. The lowest energy consumption of 3, 4, 5, and 6 was observed for 
asparagus roots slices dried in a fluidized bed dryer at $70,60,50$, and $40^{\circ} \mathrm{C}$, respectively. There was approximately a five to seven-fold difference between vacuum and fluidized bed dying's energy consumption values depending on the selected drying air temperature. The total energy consumed by $1 \mathrm{~kg}$ of chestnuts ranged from 6.47 to $25.25 \mathrm{kWh} / \mathrm{kg}$, depending on the factor that directly influenced the drying time, like drying air temperature and air velocity [69]. The results signify that increasing the drying air temperature profoundly affects energy consumption. It was found to be decreased with an increase in drying air temperature, which is due to the fact that drying at higher air temperature results in rapid drying and hence the drying time is shorter than subsequently decreases the energy consumption. Similar outcomes have been stated for drying various products like nettle leaves [70], mushroom slices [76], asparagus roots [14], and chard leaves [73].

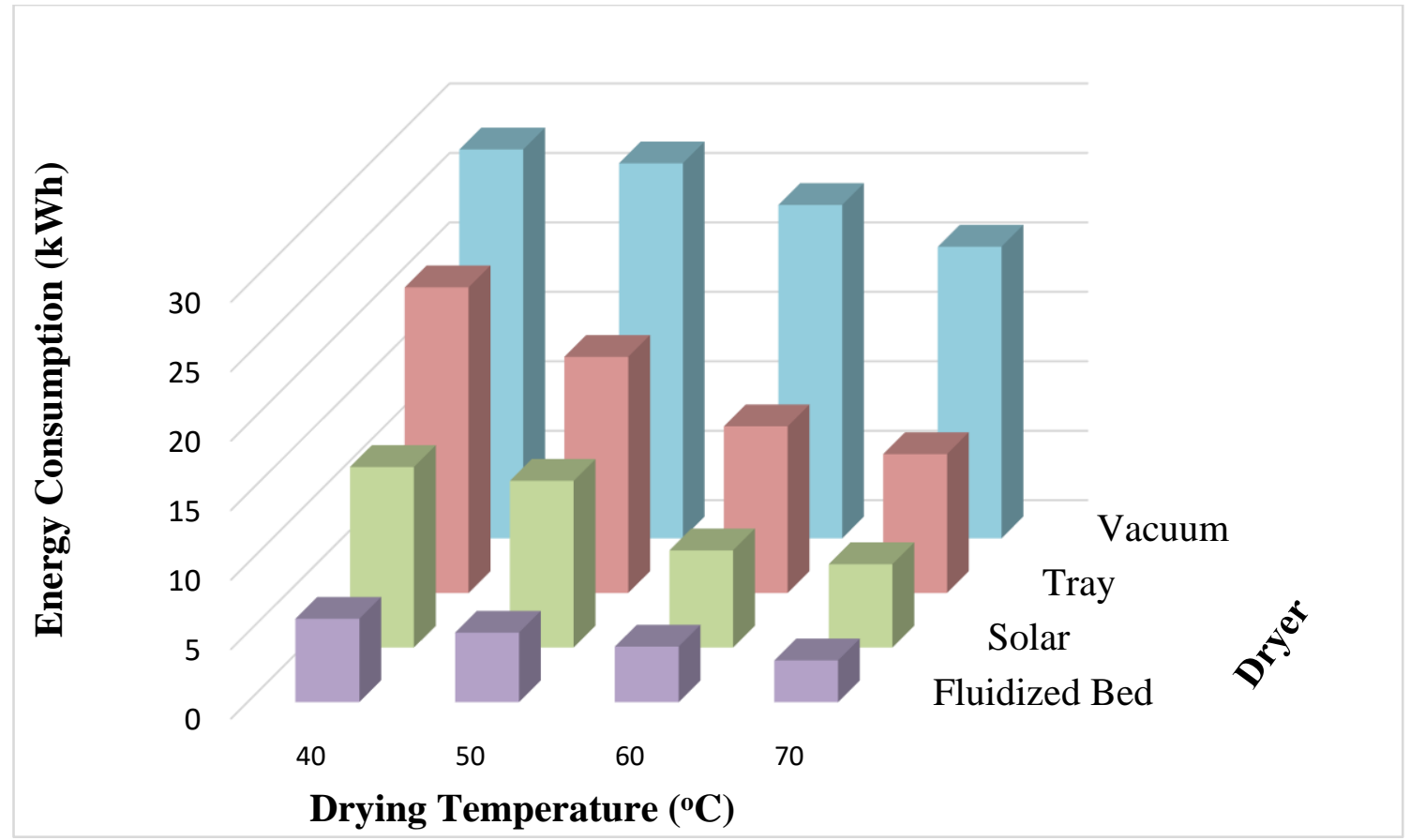

Figure 7. Energy consumption for drying of asparagus roots under different conditions.

Table 4. Effect of drying conditions on rehydration and color characteristics of asparagus roots.

\begin{tabular}{|c|c|c|c|c|c|c|c|c|}
\hline \multirow[t]{2}{*}{ Dryer } & \multirow[t]{2}{*}{ Temp. } & \multicolumn{3}{|c|}{ Rehydration Characteristics } & \multirow{2}{*}{$\begin{array}{c}\text { Dehydration } \\
\text { Ratio }\end{array}$} & \multicolumn{3}{|c|}{ Color } \\
\hline & & $\begin{array}{c}\text { Rehydration } \\
\text { Ratio } \\
\text { (RR) }\end{array}$ & $\begin{array}{c}\text { Coefficient } \\
\text { of } \\
\text { Rehydration } \\
\text { (COR) }\end{array}$ & $\begin{array}{l}\text { Percentage } \\
\text { of Water } \\
\text { (POW) }\end{array}$ & & $\mathbf{E}$ & Chroma & Hue \\
\hline \multirow[t]{4}{*}{ Vacuum } & 40 & $4.48^{\mathrm{fg}} \pm 0.167$ & $\begin{array}{c}0.624^{\mathrm{ef}} \pm \\
0.023\end{array}$ & $\begin{array}{c}78.82^{\mathrm{de}} \pm \\
0.801\end{array}$ & $\begin{array}{l}5.335^{\text {def }} \pm \\
0.226\end{array}$ & $\begin{array}{l}11.531^{\text {gh }} \\
\pm 0.084\end{array}$ & $\begin{array}{c}24.54^{\mathrm{f}} \pm \\
0.048\end{array}$ & $\begin{array}{c}71.85^{\mathrm{j}} \\
\pm \\
0.034\end{array}$ \\
\hline & 50 & $\begin{array}{c}4.565^{\mathrm{ef}} \pm \\
0.304\end{array}$ & $\begin{array}{c}0.632^{\text {def }} \pm \\
0.042\end{array}$ & $\begin{array}{c}78.98^{\mathrm{de}} \pm \\
1.358\end{array}$ & $\begin{array}{c}5.608^{\text {cdef }} \pm \\
0.353\end{array}$ & $\begin{array}{l}11.126^{\mathrm{h}} \\
\pm 0.119\end{array}$ & $\begin{array}{c}24.41^{\mathrm{f}} \pm \\
0.057\end{array}$ & $\begin{array}{c}71.75^{\mathrm{j}} \\
\pm \\
0.027\end{array}$ \\
\hline & 60 & $5.28^{a} \pm 0.187$ & $\begin{array}{c}0.725^{\mathrm{a}} \pm \\
0.026\end{array}$ & $\begin{array}{c}81.52^{\mathrm{a}} \pm \\
0.666\end{array}$ & $\begin{array}{c}6.222^{\text {abcde }} \pm \\
0.149\end{array}$ & $\begin{array}{l}19.320^{\mathrm{a}} \\
\pm 0.144\end{array}$ & $\begin{array}{c}23.02^{\mathrm{j}} \pm \\
0.113\end{array}$ & $\begin{array}{c}74.57^{\mathrm{e}} \\
\pm \\
0.063\end{array}$ \\
\hline & 70 & $4.44^{\mathrm{fg}} \pm 0.053$ & $\begin{array}{c}0.602^{\mathrm{ef}} \pm \\
0.007\end{array}$ & $\begin{array}{c}77.49^{f} \pm \\
0.267\end{array}$ & $\begin{array}{c}7.358^{\mathrm{ab}} \pm \\
0.556\end{array}$ & $\begin{array}{l}12.815^{\mathrm{ef}} \\
\pm 0.812\end{array}$ & $\begin{array}{c}23.37^{\mathrm{i}} \pm \\
0.099\end{array}$ & $\begin{array}{c}72.73^{\mathrm{i}} \\
\pm \\
0.220\end{array}$ \\
\hline \multirow[t]{2}{*}{ Tray } & 40 & $\begin{array}{c}5.14^{\mathrm{abc}} \pm \\
0.155\end{array}$ & $\begin{array}{c}0.698^{\mathrm{ab}} \pm \\
0.021\end{array}$ & $\begin{array}{c}80.60^{\mathrm{abc}} \pm \\
0.588\end{array}$ & $\begin{array}{c}7.204^{\mathrm{ab}} \pm \\
0.403\end{array}$ & $\begin{array}{l}16.661^{\mathrm{c}} \\
\pm 0.798\end{array}$ & $\begin{array}{c}26.22^{\mathrm{e}} \pm \\
0.544\end{array}$ & $\begin{array}{c}73.79^{\mathrm{f}} \\
\pm \\
0.395 \\
\end{array}$ \\
\hline & 50 & $\begin{array}{l}4.745^{\mathrm{def}} \pm \\
0.145\end{array}$ & $\begin{array}{c}0.644^{\text {cde }} \pm \\
0.020\end{array}$ & $\begin{array}{c}78.98^{\mathrm{de}} \pm \\
0.646\end{array}$ & $\begin{array}{c}7.328^{\mathrm{ab}} \pm \\
1.212\end{array}$ & $\begin{array}{l}15.013^{\mathrm{d}} \\
\pm 0.271\end{array}$ & $\begin{array}{c}23.78^{\mathrm{h}} \pm \\
0.101\end{array}$ & $\begin{array}{c}73.28^{\mathrm{g}} \\
\pm \\
0.067\end{array}$ \\
\hline
\end{tabular}




\begin{tabular}{|c|c|c|c|c|c|c|c|c|}
\hline \multirow[t]{4}{*}{ Dryer } & \multirow[t]{2}{*}{ Temp. } & \multicolumn{3}{|c|}{ Rehydration Characteristics } & \multirow{2}{*}{$\begin{array}{c}\text { Dehydration } \\
\text { Ratio }\end{array}$} & \multicolumn{3}{|c|}{ Color } \\
\hline & & $\begin{array}{c}\text { Rehydration } \\
\text { Ratio } \\
\text { (RR) }\end{array}$ & $\begin{array}{c}\text { Coefficient } \\
\text { of } \\
\text { Rehydration } \\
\text { (COR) }\end{array}$ & $\begin{array}{l}\text { Percentage } \\
\text { of Water } \\
\text { (POW) }\end{array}$ & & $\mathbf{E}$ & Chroma & Hue \\
\hline & 60 & $\begin{array}{c}5.16^{\mathrm{abc}} \pm \\
0.157\end{array}$ & $0.7^{\mathrm{ab}} \pm 0.021$ & $\begin{array}{c}80.65^{\mathrm{abc}} \pm \\
0.597\end{array}$ & $\begin{array}{c}7.330^{\mathrm{ab}} \pm \\
0.959\end{array}$ & $\begin{array}{l}12.697^{\mathrm{ef}} \\
\pm 0.339\end{array}$ & $\begin{array}{c}26.53^{\mathrm{d}} \pm \\
0.128\end{array}$ & $\begin{array}{c}73.07^{\mathrm{h}} \\
\pm \\
0.056 \\
\end{array}$ \\
\hline & 70 & $\begin{array}{c}4.94^{\mathrm{bcd}} \pm \\
0.009\end{array}$ & $\begin{array}{c}0.67^{\mathrm{bcd}} \pm \\
0.001\end{array}$ & $\begin{array}{c}79.8^{\text {bcd }} \pm \\
0.035\end{array}$ & $\begin{array}{c}7.336^{\mathrm{ab}} \pm \\
0.933\end{array}$ & $\begin{array}{l}16.294^{c} \\
\pm 0.364\end{array}$ & $\begin{array}{c}26.85^{\mathrm{c}} \pm \\
0.044\end{array}$ & $\begin{array}{c}73.61^{\mathrm{f}} \\
\pm \\
0.027\end{array}$ \\
\hline \multirow[t]{4}{*}{ Solar } & 40 & $4.23^{\mathrm{g}} \pm 0.234$ & $0.6^{\mathrm{f}} \pm 0.033$ & $\begin{array}{c}78.44^{\mathrm{ef}} \pm \\
1.182\end{array}$ & $\begin{array}{c}4.441^{\mathrm{f}} \pm \\
0.231\end{array}$ & $\begin{array}{l}11.855^{\mathrm{gh}} \\
\pm 0.161\end{array}$ & $\begin{array}{c}22.52^{\mathrm{k}} \pm \\
0.041\end{array}$ & $\begin{array}{c}75.68^{\mathrm{b}} \\
\pm \\
\pm \\
0.052\end{array}$ \\
\hline & 50 & $\begin{array}{c}4.475^{\mathrm{fg}} \pm \\
0.171\end{array}$ & $\begin{array}{c}0.631^{\mathrm{def}} \pm \\
0.024\end{array}$ & $\begin{array}{c}79.34^{\text {cde }} \pm \\
0.795\end{array}$ & $\begin{array}{c}4.736^{\mathrm{f}} \pm \\
0.378\end{array}$ & $\begin{array}{l}11.103^{\mathrm{h}} \\
\pm 0.432\end{array}$ & $\begin{array}{c}23.69^{\mathrm{h}} \pm \\
0.128\end{array}$ & $\begin{array}{c}74.79^{\mathrm{d}} \\
\pm \\
\pm \\
0.060 \\
\end{array}$ \\
\hline & 60 & $\begin{array}{c}4.915^{\mathrm{cd}} \pm \\
0.122\end{array}$ & $\begin{array}{c}0.688^{\mathrm{ab}} \pm \\
0.017\end{array}$ & $\begin{array}{c}80.93^{\mathrm{ab}} \pm \\
0.48\end{array}$ & $\begin{array}{c}5.042^{\text {ef }} \pm \\
0.322\end{array}$ & $\begin{array}{l}13.311^{\mathrm{e}} \\
\pm 0.252\end{array}$ & $\begin{array}{c}23.85^{\mathrm{h}} \pm \\
0.042\end{array}$ & $\begin{array}{c}76.12^{\mathrm{a}} \\
\pm \\
0.051\end{array}$ \\
\hline & 70 & $\begin{array}{l}4.855^{\mathrm{cde}} \pm \\
0.106\end{array}$ & $\begin{array}{c}0.668^{\mathrm{bcd}} \pm \\
0.015\end{array}$ & $\begin{array}{c}80.03^{\text {bcd }} \pm \\
0.439\end{array}$ & $\begin{array}{c}6.079^{\mathrm{bcde}} \pm \\
0.807\end{array}$ & $\begin{array}{l}11.265^{\mathrm{h}} \\
\pm 0.614\end{array}$ & $\begin{array}{c}24.14^{\mathrm{g}} \pm \\
0.109\end{array}$ & $\begin{array}{c}71.82^{\mathrm{j}} \\
\pm \\
0.093\end{array}$ \\
\hline \multirow[t]{4}{*}{$\begin{array}{l}\text { Fluidized } \\
\text { bed }\end{array}$} & 40 & $\begin{array}{c}5.045^{\text {abcd }} \pm \\
0.225\end{array}$ & $\begin{array}{c}0.691^{\mathrm{ab}} \pm \\
0.031\end{array}$ & $\begin{array}{c}80.55^{\mathrm{abc}} \pm \\
0.892\end{array}$ & $\begin{array}{c}6.429^{\mathrm{abcd}} \pm \\
0.482\end{array}$ & $\begin{array}{l}18.235^{\mathrm{b}} \\
\pm 0.128\end{array}$ & $\begin{array}{c}27.28^{\mathrm{b}} \pm \\
0.024\end{array}$ & $\begin{array}{c}75.13^{\mathrm{c}} \\
\pm \\
0.036 \\
\end{array}$ \\
\hline & 50 & $\begin{array}{c}5.07^{\mathrm{abc}} \pm \\
0.180\end{array}$ & $\begin{array}{c}0.692^{\mathrm{ab}} \pm \\
0.025\end{array}$ & $\begin{array}{c}80.54^{\mathrm{abc}} \pm \\
0.694\end{array}$ & $\begin{array}{c}6.727^{\mathrm{abc}} \pm \\
0.669\end{array}$ & $\begin{array}{l}18.812^{\mathrm{ab}} \\
\pm 0.784\end{array}$ & $\begin{array}{c}26.45^{\mathrm{de}} \pm \\
0.099\end{array}$ & $\begin{array}{c}74.81^{\mathrm{d}} \\
\pm \\
0.132 \\
\end{array}$ \\
\hline & 60 & $\begin{array}{c}5.245^{\mathrm{ab}} \pm \\
0.079\end{array}$ & $\begin{array}{c}0.712^{\mathrm{ab}} \pm \\
0.011\end{array}$ & $\begin{array}{c}80.96^{\mathrm{ab}} \pm \\
0.288\end{array}$ & $\begin{array}{c}7.368^{\mathrm{ab}} \pm \\
0.920\end{array}$ & $\begin{array}{l}14.732^{\mathrm{d}} \\
\pm 0.032\end{array}$ & $\begin{array}{c}27.92^{\mathrm{a}} \pm \\
0.048\end{array}$ & $\begin{array}{c}73.79^{f} \\
\pm \\
0.010\end{array}$ \\
\hline & 70 & $\begin{array}{c}4.99^{\mathrm{abcd}} \pm \\
0.117\end{array}$ & $\begin{array}{c}0.677^{\mathrm{bc}} \pm \\
0.016\end{array}$ & $\begin{array}{c}79.98^{\text {bcd }} \pm \\
0.472\end{array}$ & $\begin{array}{c}7.482^{\mathrm{a}} \pm \\
1.312\end{array}$ & $\begin{array}{l}12.264^{\text {fg }} \\
\pm 0.129\end{array}$ & $\begin{array}{c}24.54^{\mathrm{f}} \pm \\
0.030\end{array}$ & $\begin{array}{c}73.83^{\mathrm{f}} \\
\pm \\
0.037\end{array}$ \\
\hline
\end{tabular}

Note: Values are stated as mean \pm SD and means with different letters in the same line are significantly different $(\mathrm{p}<0.05)$

\section{Conclusions}

In this present study, the effects of the tray, solar, fluidized bed, and vacuum drying on the drying characteristics, rehydration characteristics, color characteristics, and energy consumption for drying of asparagus roots were investigated. The results demonstrated that the drying conditions significantly affected the kinetics and quality of dried asparagus roots. The drying at a higher temperature result in less drying time and hence the low energy consumption data and superior rehydration characteristics. Rehydration ratio increases with a decrease in temperature from $70-60{ }^{\circ} \mathrm{C}$ but decreases with a further decrease in temperature from $60-40^{\circ} \mathrm{C}$. The color characteristics (Chroma, hue angle, and $\Delta \mathrm{E}$ ) of dried asparagus samples show fewer color changes after drying. Among the selected drying approaches, vacuum drying shows superior color characteristics. Thus, for the superior quality of dried products, dehydration at optimum temperature is necessary. The cubic model was found best to define the drying performance of asparagus as SSE and RMSE were least and the R2 was highest compared to other models. Future investigation is required to add knowledge regarding the change in characteristics of different chemical compositions and the structural properties of asparagus.

\section{Funding}

This research received no external funding. 


\section{Acknowledgments}

This research has no acknowledgments.

\section{Conflicts of Interest}

The authors declare no conflict of interest.

\section{References}

1. Bopana, N.; Saxena, S. Asparagus racemosus--ethnopharmacological evaluation and conservation needs. Journal of Ethnopharmacology 2007, 110, 1-15, https://doi.org/10.1016/j.jep.2007.01.001.

2. Joshi, V.K.; Joshi, A.; Dhiman, K.S. The Ayurvedic Pharmacopoeia of India, development and perspectives. Journal of Ethnopharmacology 2017, 197, 32-38, https://doi.org/10.1016/j.jep.2016.07.030.

3. Singh, R.; Geetanjali. Asparagus racemosus: a review on its phytochemical and therapeutic potential. Natural Product Research. 2016, 30, 1896-1908, https://doi.org/10.1080/14786419.2015.1092148.

4. Kashyap, P.; Muthusamy, K.; Niranjan, M.; Trikha, S.; Kumar, S. Sarsasapogenin: A steroidal saponin from Asparagus racemosus as multi target directed ligand in Alzheimer's disease. Steroids 2020, 153, 108529, https://doi.org/10.1016/j.steroids.2019.108529.

5. Parihar, M.S.; Hemnani, T. Experimental excitotoxicity provokes oxidative damage in mice brain and attenuation by extract of Asparagus racemosus. Journal of Neural Transmission 2004, 111, 1-12, https://doi.org/10.1007/s00702-003-0069-8.

6. Sharma, U.; Kumar, N.; Singh, B.; Munshi, R.K.; Bhalerao, S. Immunomodulatory active steroidal saponins from Asparagus racemosus. Medicinal Chemistry Research 2013, 22, 573-579, https://doi.org/10.1007/s00044-012-0048-4.

7. Zhang, H.; Birch, J.; Pei, J.; Ma, Z.F.; Bekhit, A.E. Phytochemical compounds and biological activity in Asparagus roots: a review. International Journal of Food Science \& Technology 2019, 54, 966-977, https://doi.org/10.1111/ijfs.13993.

8. Dikasso, D.; Makonnen, E.; Debella, A., et al. In vivo anti-malarial activity of hydroalcoholic extracts from Asparagus africanus Lam. in mice infected with Plasmodium berghei. The Ethiopian Journal of Health Development 2006, 20, 112-118.

9. Jalalpure, S.; Bagewadi, V.; Shaikh, I. Antiepileptic Effect of Asparagus racemosus Root Extracts. Journal of Tropical Medicinal Plants 2009, 10, 157-161.

10. Acharya, S.R.; Acharya, N.S.; Bhangale, J.O.; Shah, S.K.; Pandya, S.S. Antioxidant and hepatoprotective action of Asparagus racemosus Willd. root extracts. Indian Journal of Experimental Biology 2012, 50, 795801.

11. Goel, R.K.; Prabha, T.; Kumar, M.M.; Dorababu, M.; Singh, G. Teratogenicity of Asparagus racemosus Willd. root, a herbal medicine. Indian Journal of Experimental Biology 2006, 44, 570-573.

12. Muruganandan, S.; Garg, H.; Lal, J.; Suresh, C.; Dinesh, K. Studies on the immunostimulant and antihepatotoxic activities of Asparagus racemosus root extract. Journal of Medicine Aromatic Plant Science 2001, 22, 49-52.

13. Sairam, K.; Priyambada, S.; Aryya, N.C.; Goel, R.K. Gastroduodenal ulcer protective activity of Asparagus racemosus: an experimental, biochemical and histological study. Journal of ethnopharmacology 2003, 86, 110, https://doi.org/10.1016/s0378-8741(02)00342-2.

14. Kohli, D.; Shahi, N.C.; Pandey, J.P.; Singh, A. Drying of Asparagus Roots in Solar and Fluidised Bed Dryer. International Journal of Agriculture Sciences 2017, 9, 4072-4076.

15. Kohli, D.; Kumar, A.; Kumar, S.; Upadhyay, S. Waste Utilization of Amla Pomace and Germinated Finger Millets for Value Addition of Biscuits. Current Research in Nutrition and Food Sciences 2019, 7, $272-279$.

16. Kovac1, T.; Dikmen, E.; Şencan Şahin, A. Mathematical model for mint drying kinetics prediction by freezedrying process: Gene expression programming. Journal of Food Process Engineering 2020, 43, e13380, https://doi.org/10.1111/jfpe.13380.

17. Zheng, Q.; Li, X.; Liu, T., Zhang, H.; Li, W.; Gao, X. Effects of air-impingement jet drying on drying kinetics, color, polyphenol compounds, and antioxidant activities of Boletus aereus slices. Journal of Food Science 2021, 86, 2131-2144, https://doi.org/10.1111/1750-3841.15702.

18. Yarahmadi, N.; Hojjatoleslamy, M.; Sedaghat Boroujeni, L. Different drying methods of Pistacia Atlantica seeds: Impact on drying kinetics and selected quality properties. Food Science \& Nutrition 2020, 8, 32253233, https://doi.org/10.1002/fsn3.1582.

19. Oladejo, A.O.; Ekpene, M.-A.M.; Onwude, D.I.; Assian, U.E.; Nkem, O.M. Effects of ultrasound pretreatments on the drying kinetics of yellow cassava during convective hot air drying. Journal of Food Processing and Preservation 2021, 45, e15251, https://doi.org/10.1111/jfpp.15251. 
20. Venkatachalam, S.K.; Thottipalayam Vellingri, A.; Selvaraj, V. Low-temperature drying characteristics of mint leaves in a continuous-dehumidified air drying system. Journal of Food Process Engineering 2020, 43, e13384, https://doi.org/10.1111/jfpe.13384.

21. Wang, X.; Gao, Y.; Zhao, Y.; Li, X.; Fan, J.; Wang, L. Effect of different drying methods on the quality and microstructure of fresh jujube crisp slices. Journal of Food Processing and Preservation 2021, 45, e15162, https://doi.org/10.1111/jfpp.15162.

22. Macedo, L.L.; Vimercati, W.C.; da Silva Araújo, C.; Saraiva, S.H.; Teixeira, L.J.Q. Effect of drying air temperature on drying kinetics and physicochemical characteristics of dried banana. Journal of Food Process Engineering 2020, 43, e13451, https://doi.org/10.1111/jfpe.13451.

23. Bakhshipour, A.; Zareiforoush, H.; Bagheri, I. Mathematical and intelligent modeling of stevia (Stevia Rebaudiana) leaves drying in an infrared-assisted continuous hybrid solar dryer. Food Science \& Nutrition 2021, 9, 532-543, https://doi.org/10.1002/fsn3.2022.

24. Alibas, I.; Zia, M.P.; Yilmaz, A.; Asik, B.B. Drying kinetics and quality characteristics of green apple peel (Mallus communis L. var. "Granny Smith") used in herbal tea production. Journal of Food Processing and Preservation 2020, 44, e14332, https://doi.org/10.1111/jfpp.14332.

25. Shende, D.; Datta, A.K. Optimization study for refractance window drying process of Langra variety mango. Journal of Food Science and Technology 2020, 57, 683-692, https://doi.org/10.1007/s13197-019-04101-0.

26. Özcan, M.M.; Ghafoor, K.; Al Juhaimi, F., et al. Influence of drying techniques on bioactive properties, phenolic compounds and fatty acid compositions of dried lemon and orange peel powders. Journal of Food Science and Technology 2021, 58, 147-158, https://doi.org/10.1007/s13197-020-04524-0.

27. Kannan, V.S.; Arjunan, T.V.; Vijayan, S. Drying characteristics of mint leaves (Mentha arvensis) dried in a solid desiccant dehumidifier system. Journal of Food Science and Technology 2021, 58, 777-786, https://doi.org/10.1007/s13197-020-04595-z.

28. Onwude, D.I.; Hashim, N.; Chen, G.; Putranto, A.; Udoenoh, N.R. A fully coupled multiphase model for infrared-convective drying of sweet potato. Journal of the Science of Food and Agriculture 2021, 101, 398413, https://doi.org/10.1002/jsfa.10649.

29. Al-Hilphy, A.R.; Gavahian, M.; Barba, F.J.; Lorenzo, J.M.; Al-Shalah, Z.M.; Verma, D.K. Drying of sliced tomato (Lycopersicon esculentum L.) by a novel halogen dryer: Effects of drying temperature on physical properties, drying kinetics, and energy consumption. Journal of Food Process Engineering 2021, 44, e13624, https://doi.org/10.1111/jfpe.13624.

30. Song, B.; Tan, H.; Yang, J. Effect of three drying methods on the drying kinetics and quality of acerola cherry. Journal of Food Processing and Preservation 2020, 44, e14674, https://doi.org/10.1111/jfpp.14674.

31. Omar,i A.; Behroozi-Khazaei, N.; Sharifian, F. Drying kinetic and artificial neural network modeling of mushroom drying process in microwave-hot air dryer. Journal of Food Process Engineering 2018, 41, e12849, https://doi.org/10.1111/jfpe.12849.

32. Antal, T.; Kerekes, B.; Sikolya, L.; Tarek, M. Quality and Drying Characteristics of Apple Cubes Subjected to Combined Drying (FD Pre-Drying and HAD Finish-Drying). Journal of Food Processing and Preservation 2015, 39, 994-1005, https://doi.org/10.1111/jfpp.12313.

33. Zhang, F.; Zhang, M.; Mujumdar, A.S. Drying Characteristics and Quality of Restructured Wild Cabbage Chips Processed Using Different Drying Methods. Drying Technology 2011, 29, 682-688, https://doi.org/10.1080/07373937.2010.525729.

34. Miraei Ashtiani, S.-H.; Salarikia, A.; Golzarian, M.R. Analyzing drying characteristics and modeling of thin layers of peppermint leaves under hot-air and infrared treatments. Information Processing in Agriculture 2017, 4, 128-139, https://doi.org/10.1016/j.inpa.2017.03.001.

35. Bualuang, O.; Onwude, D.I.; Uso, A., et al. Determination of drying kinetics, some physical, and antioxidant properties of papaya seeds undergoing microwave vacuum drying. Journal of Food Process Engineering 2019, 42, 1-12, https://doi.org/10.1111/jfpe.13176.

36. Bala, B.K.; Hoque, M.A.; Hossain, M.A.; Uddin, M.B. Drying Characteristics of Asparagus Roots (Asparagus racemosus Wild.). Drying Technology 2010, 28, 533-541, https://doi.org/10.1080/07373931003618899.

37. AOAC. Official methods of analysis of the Association of Official Analytical Chemists. Arlington, VA: The Association; 1990.

38. Jokić, S.; Mujić, I.; Martinov, M.; Velić, D.; Bilić, M.; Lukinac J. Influence of drying procedure on colour and rehydration characteristic of wild asparagus. Czech journal of food sciences 2009, 27, 171-177.

39. Nindo, C.I.; Sun, T.; Wang, S.W.; Tang, J.; Powers, J.R. Evaluation of drying technologies for retention of physical quality and antioxidants in asparagus (Asparagus officinalis, L.). LWT - Food Science and Technology 2003, 36, 507-516, https://doi.org/10.1016/S0023-6438(03)00046-X.

40. Janjai, S.; Srisittipokakun, N.; Bala, B.K. Experimental and modelling performances of a roof-integrated solar drying system for drying herbs and spices. Energy 2008, 33, 91-103.

41. Roberts, J.; Kidd, D.; Padilla-Zakour, O. Drying kinetics of grape seeds. Journal of Food Engineering 2008, 89, 460-465, https://doi.org/10.1016/j.jfoodeng.2008.05.030.

42. Midilli, A. Determination of pistachio drying behaviour and conditions in a solar drying system. International Journal of Energy Research 2001, 25, 715-725, https://doi.org/10.1002/er.715. 
43. Hashim, N.; Daniel, O.; Rahaman, E. A Preliminary Study: Kinetic Model of Drying Process of Pumpkins (Cucurbita Moschata) in a Convective Hot Air Dryer. Agriculture and Agricultural Science Procedia 2014, 2, 345-352, https://doi.org/10.1016/j.aaspro.2014.11.048.

44. Ayadi, M.; Mabrouk, S.; Zouari, I.; Bellagi, A. Kinetic study of the convective drying of spearmint. Journal of the Saudi Society of Agricultural Sciences 2013, 13, 1-7, https://doi.org/10.1016/j.jssas.2013.04.004.

45. Ponkham, K.; Meeso, N.; Soponronnarit, S.; Siriamornpun, S. Modeling of combined far-infrared radiation and air drying of a ring shaped-pineapple with/without shrinkage. Food and Bioproducts Processing 2012, 90, 155-164, https://doi.org/10.1016/j.fbp.2011.02.008.

46. Compaore, A.; Putranto, A.; Dissa, A.O., et al. Convective drying of onion: modeling of drying kinetics parameters. Journal of Food Science and Technology 2019, 56, 3347-3354, https://doi.org/10.1007/s13197019-03817-3.

47. Goyal, R.; Ambrose, K.; Ramarathinam, M.; Ilyas, S. Thin-layer Drying Kinetics of Raw Mango Slices. Biosystems Engineering 2006, 95, 43-49, https://doi.org/10.1016/j.biosystemseng.2006.05.001.

48. Kumar, P.S.; Nambi, E.; Shiva, K.N., et al. Thin layer drying kinetics of Banana var. Monthan (ABB): Influence of convective drying on nutritional quality, microstructure, thermal properties, color, and sensory characteristics. Journal of Food Process Engineering 2019, 42, e13020, https://doi.org/10.1111/jfpe.13020.

49. Franco, T.S.; Perussello, C.A.; Ellendersen, L.N.; Masson, M.L. Effect of Process Parameters on Foam Mat Drying Kinetics of Yacon (Smallanthus sonchifolius) and Thin-Layer Drying Modeling of Experimental Data. Journal of Food Process Engineering 2017, 40, e12264, https://doi.org/10.1111/jfpe.12264.

50. Doymaz, I.; Ismail, O. Drying characteristics of sweet cherry. Food and Bioproducts Processing 2011, 89, 31-38, https://doi.org/10.1016/j.fbp.2010.03.006.

51. Doymaz, I.; Ismail, O. Experimental characterization and modelling of drying of pear slices. Food Science and Biotechnology 2012, 21, 1377-1381, https://doi.org/10.1007/s10068-012-0181-3.

52. Kohli, D.; Shahi, N.C.; Kumar, A. Drying Kinetics and Activation Energy of Asparagus Root (Asparagus racemosus Wild.) for Different Methods of Drying. Current Research in Nutrition and Food Science 2018, 6, 191-202, http://dx.doi.org/10.12944/CRNFSJ.6.1.22.

53. Toğrul, İ.T.; Pehlivan, D. Mathematical modelling of solar drying of apricots in thin layers. Journal of Food Engineering 2002, 55, 209-216, https://doi.org/10.1016/S0260-8774(02)00065-1.

54. Onwude, D.I.; Hashim, N.; Janius, R.B.; Nawi, N.M.; Abdan, K. Modeling the Thin-Layer Drying of Fruits and Vegetables: A Review. Comprehensive Reviews in Food Science and Food Safety 2016, 15, 599-618, https://doi.org/10.1111/1541-4337.12196.

55. Altay, K.; Hayaloglu, A.A.; Dirim, S.N. Determination of the drying kinetics and energy efficiency of purple basil (Ocimum basilicum L.) leaves using different drying methods. Heat and Mass Transfer 2019, 55, 2173 2184, https://doi.org/10.1007/s00231-019-02570-9.

56. da Silva, W.P.; Rodrigues, A.F.; Silva, C.M.; de Castro, D.S.; Gomes, J.P. Comparison between continuous and intermittent drying of whole bananas using empirical and diffusion models to describe the processes. Journal of Food Engineering 2015, 166, 230-236, https://doi.org/10.1016/j.jfoodeng.2015.06.018.

57. Omolola, A.; Jideani, A.; Kapila, P. Modeling microwave drying kinetics and moisture diffusivity of Mabonde banana variety. International Journal of Agricultural and Biological Engineering 2014, 7, 107113, https://doi.org/10.3965/j.ijabe.20140706.013.

58. Alibas, I. Microwave, Air and Combined Microwave-Air Drying of Grape Leaves (Vitis vinifera L.) and the Determination of Some Quality Parameters. International journal of food engineering 2014, 10, 69-88, https://doi.org/10.1515/ijfe-2012-0037.

59. Süfer, Ö.; Sezer, S.; Demir, H. Thin layer mathematical modeling of convective, vacuum and microwave drying of intact and brined onion slices. Journal of Food Processing and Preservation 2017, 41, 1-13, https://doi.org/10.1111/jfpp.13239.

60. Dalvand, M.; Mohtasebi, S.; Rafiee, S. Determining the influence of drying conditions on EHD drying process. Journal of Agricultural and Biological Science 2012, 7, 396-401.

61. Velić, D.; Planinić, M.; Tomas, S.; Bilić, M. Influence of airflow velocity on kinetics of convection apple drying. Journal of Food Engineering 2004, 64, 97-102, https://doi.org/10.1016/j.jfoodeng.2003.09.016.

62. Ranganna, S. Handbook of analysis and quality control for fruit and vegetable products. 2 ed: Tata McGrawHill Education, New Delhi, India; 1986.

63. Kumar, S.; Chand, K.; Kohli, D.; Mishra, R. Practical Approaches in Food Science and Technology. New Delhi: Renu Publishers; 2017.

64. Sagar, V.R. Preparation of onion powder by means of osmotic dehydration and its packaging and storage. Journal of Food Science and Technology-Mysore- 2001, 38, 525-528.

65. Davoodi, M.G.; Vijayanand, P.; Kulkarni, S.G.; Ramana, K.V.R. Effect of different pre-treatments and dehydration methods on quality characteristics and storage stability of tomato powder. LWT - Food Science and Technology 2007, 40, 1832-1840, https://doi.org/10.1016/j.lwt.2006.12.004.

66. Yildiz, G.; İzli, G. Influence of microwave and microwave-convective drying on the drying kinetics and quality characteristics of pomelo. Journal of Food Processing and Preservation 2019, 43, e13812, https://doi.org/10.1111/jfpp.13812. 
67. Yildiz, G.; Rababah, T.; Feng, H. Ultrasound-Assisted Cutting of Cheddar, Mozzarella and Swiss Cheeses Effects on Quality Attributes during Storage. Innovative Food Science \& Emerging Technologies 2016, 37, 1-9, https://doi.org/10.1016/j.ifset.2016.07.013.

68. Guiné, R.; Barroca, M. Effect of drying treatments on texture and color of vegetables (pumpkin and green pepper). Food and Bioproducts Processing 2012, 90, 58-63, https://doi.org/10.1016/j.fbp.2011.01.003.

69. Vithhal, R.; Sharma, G.P.; Verma, R.C.; Jain, S.K.; Chahar, V.K. Drying Behaviour and Energy Requirement for Dehydration of White Onion Slices. International Journal of Food Engineerin. 2007, 3, 1-16, https://doi.org/10.2202/1556-3758.1077.

70. Alibas, I. Energy Consumption and Colour Characteristics of Nettle Leaves during Microwave, Vacuum and $\begin{array}{lllll}\text { Convective } & \text { Drying. } & \text { Biosystems } & \text { Engineering }\end{array}$ https://doi.org/10.1016/j.biosystemseng.2006.12.011.

71. Lee, J.-H.; Kim, H.-J. Drying kinetics of onion slices in a hot-air dryer. Journal of Food Science and Nutrition 2008, 13, 225-230.

72. Doymaz, I. Drying of Thyme (Thymus Vulgaris L.) and Selection of a Suitable Thin-Layer Drying Model. Journal of Food Processing and Preservation 2011, 35, 458-465, https://doi.org/10.1111/j.17454549.2010.00488.x.

73. Alibas, I. Characteristics of Chard Leaves during Microwave, Convective, and Combined MicrowaveConvective Drying. Drying Technology 2006, 24, 1425-1435, https://doi.org/10.1080/07373930600952776.

74. Doymaz, I. Mathematical Modelling of Thin-layer Drying of Kiwifruit Slices. Journal of Food Processing and Preservation 2009, 33, 145-160, https://doi.org/10.1111/j.1745-4549.2008.00289.x.

75. Mota, C.L.; Luciano, C.; Dias, A.; Barroca, M.J.; Guiné, R.P.F. Convective drying of onion: Kinetics and nutritional evaluation. Food and Bioproducts Processing 2010, 88, 115-123, https://doi.org/10.1016/j.fbp.2009.09.004.

76. Motevali, A.; Minaei, S.; Khoshtaghaza, M.H.; Amirnejat, H. Comparison of energy consumption and specific energy requirements of different methods for drying mushroom slices. Energy 2011, 36, 6433-6441, https://doi.org/10.1016/j.energy.2011.09.024. 